\title{
$\mathrm{C}|\mathrm{E}| \mathrm{D}|\mathrm{L}| \mathrm{A} \mid \mathrm{S}$
}

Centro de Estudios

Distributivos, Laborales y Sociales

Maestría en Economía

Facultad de Ciencias Económicas

Universidad Nacional de la Plata

\section{A Quantitative Framework for Assessing Public Investment in Tourism - An Application to Haiti}

Onil Banerjee y Martin Cicowiez

Documento de Trabajo Nro. 180

Marzo, 2015

ISSN 1853-0168 
A Quantitative Framework for Assessing Public Investment in Tourism- An Application to Haiti

\author{
Onil Banerjee ${ }^{*}$ and Martin Cicowiez ${ }^{* *}$
}

*** Infrastructure and Environment Sector - Inter-American Development Bank; e-mail: onilb@iadb.org.

${ }^{* *}$ Center for Distributive, Labor and Social Studies - Universidad Nacional de la Plata. 


\begin{abstract}
This study develops a linked regional computable general equilibrium and micro-simulation (RCGE-MS) model to assess the regional economy-wide and poverty impacts of a US $\$ 36$ million investment in tourism in the south of Haiti. The first social accounting matrix for Haiti with a base year of 2012/2013 was constructed to calibrate the model. This research addresses three key gaps identified in the tourism impact assessment literature. First, a destination-specific tourism demand and value chain analysis was used to calibrate the shocks implemented in the model. Second, the RCGE-MS approach moves beyond the representative household configuration to enable more robust analysis of tourism investment impacts on poverty and income inequality. Third, results of this modelling were used to inform a social cost-benefit analysis to provide greater transparency in the evaluation of trade-offs between investment alternatives. Considering the investment and projected tourism demand, results show a positive impact on sectoral activity, especially for the hotel and restaurant sector (182.1\% in 2040). The investment leads to a 2.0\% increase in Gross Regional Product in 2040 compared with the baseline. The South Department's exports are 4.7\% below baseline in 2040 and imports are 6.1\% higher due to the inflow of foreign exchange and the consequent appreciation of the regional real exchange rate, increased demand for most goods and services, and limited regional productive capacity. The rate of unemployment falls, beginning at $26 \%$ in 2013 and ending at $23.4 \%$ by 2040. The investment helps lift some of the poorest in the Haiti's South out of poverty, reducing the poverty headcount by 1.6 percentage points. Driving this result is an increase in employment, the average wage and non-labor income. The linked RCGE-MS approach proves to be a powerful tool for assessing how tourism investments affect regional economic activity and revealing the mechanisms through which tourism can contribute to increase employment opportunities and reduce poverty.
\end{abstract}

Keywords: tourism investment, economy-wide modelling, Haiti, microsimulation, pro-poor tourism investment, poverty. 


\section{Introduction}

Haiti is the poorest country in the Western Hemisphere and one of the poorest in the world. In 2012, Gross National Income per capita was US\$760. Of Haiti's population of 10.2 million, over half live on less than US\$1 per day and $80 \%$ live on less than US\$2 per day. Haiti is also extremely unequal; based on 2012 household survey data, Haiti has a Gini coefficient of 0.61, which has remained constant since 2001 (World Bank, 2014).

International donors have re-doubled efforts to stimulate economic growth and development in Haiti following the devastating impact of the 2010 earthquake. Investment in basic public services and in key productive sectors such as agriculture and manufacturing is needed, all within a context of regulatory reform. Recently, attention has been focused on catalyzing the resurrection of tourism. Haiti was once a well-known tourist destination considered the "pearl of the Antilles" and was one of the most frequented islands in the Caribbean from the 1950s to the 1980s. Thirty years of dictatorship rule and two decades of political and institutional crises, however, have all but erased Haiti from the tourist map for even the more adventure-minded global travelers (Trevelyan, 2013).

Despite these challenges, tourism demand has been growing in recent years. Since 2007, Haiti received the highest volume of tourists during the first quarter of 2013 and between 2007 and 2011 , international tourist volumes increased on average by $4.9 \%$ per year. In 2013 , tourism contributed US\$355.4 million (4.2\% of Gross Domestic Product) and 139,000 jobs (3.6\% of total employment) considering direct and indirect linkages (WTTC, 2014).

The government led by President Michel Martelly is the first to actively support tourism as a driver of growth. Based on Haiti's Tourism Master Plan, the South Coast, extending from Port a Piment to Jacmel, is a priority region for development (figure 1). The government's vision calls for the development and consolidation of complementary new and improved tourism options. The Inter-American Development Bank has committed to support tourism development in Haiti through a US\$36 million investment in the Sustainable Coastal Tourism Program. The Program's main lines of action include development of the tourism product through the enhancement of public tourist attractions; inclusion of local populations into the tourism value chain; basic infrastructure and services to attend to local and tourist needs, and; institutional strengthening and capacity building for improved management and development of the sector.

In this paper we develop a regional recursive dynamic Computable General Equilibrium (RCGE) model to evaluate the economic impact of this $\$ 36$ million investment in tourism. The model shock is calibrated using the results of survey-based tourism demand projections (Banerjee, Velasco and Torres, 2014) with and without the investment. A tourism value chain analysis was conducted to provide information on how tourism expenditure is allocated across sectors (Armitt, Ashley, \& Goodwin, 2014). To understand the impacts of the investment on poverty, the RCGE model is linked with a microsimulation model (RCGE-MS) which enables poverty and income inequality indices to be estimated. 
The section that follows provides a brief discussion on how tourism is thought to affect local economies and populations. Section three presents the data and methods while section four describes the scenarios and results. The final section concludes with a discussion of the key findings and their relevance for informing future tourism investments in regions with high levels of poverty and incipient tourism development.

Figure 1. Haiti's South Department and Program primary Zones of Influence.

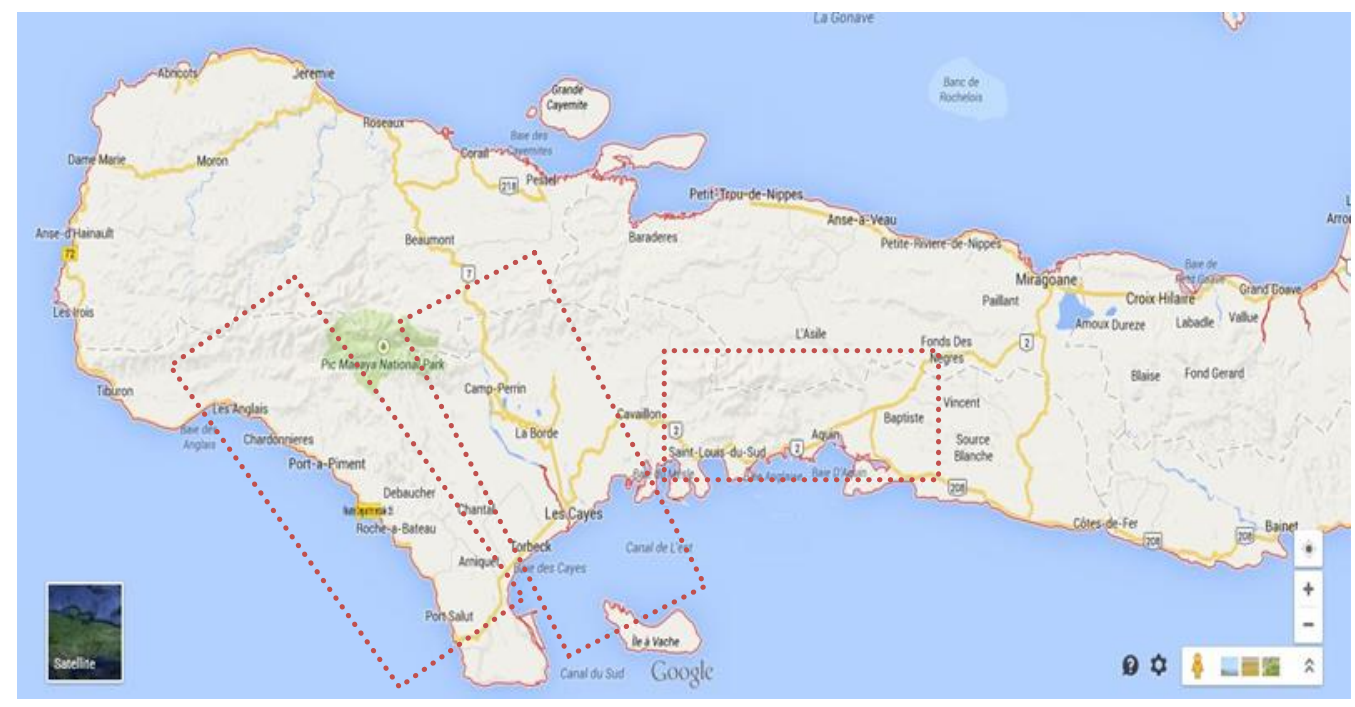

Source: Google Maps, 2014.

\section{Background}

The conventional view of tourism investment is that it is a driver of economic growth and development has significant potential for poverty alleviation. In developing country contexts, tourism can provide a major source of new off-farm income in rural areas and help bridge inequalities between overpopulated urban areas, such as Port-au-Prince, and rural areas such as the South Coast. An increase in tourism demand can stimulate increased output from tourismrelated sectors through direct, indirect and induced impacts where links between the tourism sector and other economic sectors exist. Where these linkages are strong, the well-publicized and often misused, multiplier effects of tourism investment arise (Gretton, 2013; Vanhove, 2005). Direct impacts can include: employment generation, skill creation, higher wages, and new or improved access to basic services and infrastructure, while indirect channels include price and demand effects for land and local products including agriculture and food/beverage processing (Klytchnikova \& Dorosh, 2012).

Contrary to this conventional view, some argue that expansion of the tourism sector may come at the expense of output from other sectors through crowding out effects, depending on factor supply constraints of labor, capital and land (Banerjee, 2014; Buiter, 1976). Crowding out 
implies higher input prices, and reduced competitiveness in traditional export and importcompeting markets through exchange rate appreciation. The resulting higher prices can erode the price-competitiveness of up and coming tourism destinations. Furthermore, where public resources are used to finance tourism investment, private consumption growth tends to slow thereby constraining the potential positive income and employment impacts of tourism-based growth. Thus, to assess the net welfare impact of tourism investment, country-context is critical, especially the consideration of factor supply constraints, domestic capacity to service the tourism sector, and the macroeconomic and fiscal policy environment (Dwyer, Forsyth, Madden, \& Spurr, 2000; Dwyer, Forsyth, \& Spurr, 2003, 2004).

To explore the questions raised by these two arguments, a framework that considers all economic sectors and their inter-linkages is essential. The tourism sector is not an isolated sector, rather it is composed of many sectors such as the hotel/restaurant sector, food and beverages, and transportation to name a few. Similarly, investments in tourism also target diverse sectors, from infrastructure development, the provision of basic public services such as water and sanitation, and capacity building in the services sector, as well as institutional strengthening in terms of tourism-sector governance. With its core database constructed from complete national accounts, an economy-wide RCGE framework captures all economic sectors and transactions between agents and sectors in the economy and is therefore a powerful approach for examining the net impacts of tourism investment.

In the first view where tourism is assumed to be a driver of growth, one of the key mechanisms by which this occurs is by providing off-farm and new income opportunities in rural areas. An RCGE framework enables tracking of the movement of labor between urban and rural areas, and between agriculture and tourism-related sectors. These inter-sectoral interactions remain largely obscured when analyzed in a partial equilibrium framework. In the second view, where factor supply constraints can result in higher prices, an appreciation of the real exchange rate and reduced export competitiveness, these interactions are captured in the RCGE framework where factor supply constraints are imposed. This feature of the RCGE framework is a significant improvement over multiplier or input output models which assume unlimited factor supply.

Finally, where we are concerned with the welfare impacts of tourism investments, the RCGE-MS approach developed here enables us to capture the macro effects of tourism investment alternatives, including changes on regional and sectoral output, consumption and investment through the RCGE model simulations, while the linked MS model translates changes in macro variables into household level impacts in terms of income, employment and poverty at the level of individual households ${ }^{1}$.

\footnotetext{
${ }^{1}$ It is important to note that the robustness of this micro-level analysis is a function of the quality of the household level survey data.
} 


\section{Methods and Data}

\subsection{A Regional Computable General Equilibrium Model}

In this study, we develop a single small open regional economy computable general equilibrium model to evaluate the economic impact of a \$36 million investment in tourism in Haiti's South Department. The model integrates a relatively standard recursive dynamic computable general equilibrium (CGE) model with additional equations and variables that single out: (i) the trade relations between the regional economy and the rest of the country; (ii) the domestic and foreign tourism demand, and; (iii) the impact of public capital investment in infrastructure on sectoral productivity. Thus, compared to other CGE models, the RCGE developed here provides a combination of policy-relevant features for the study of tourism investment or policy counterfactual scenarios in a regional economy. In Appendix A, the variables and equations of the RCGE model are presented. ${ }^{2}$

Figure 2 depicts the circular flow of income within the regional economy and between the regional economy and the rest of the country and world. Activities are industries that both demand (as intermediate inputs) and supply goods and services. Goods and services are consumed by households and governments, and are supplied to export markets and foreign tourists. Activities also demand factors of production (labor, capital, land, natural resources) for their productive processes and make payments to these factors. These payments are transferred to households in the form of wages and rents. Households may also receive income from transfers from the government and transfers from the rest of the country or world (migrant labor, remittances, government subsidies, gifts, etc.). Households pay taxes, consume and save through investment in the capital account.

\footnotetext{
${ }^{2}$ Alternatively, the local economy-wide impact evaluation (LEWIE) approach proposed by Taylor and others could have been implemented (Taylor \& Filipski, 2014). However, given data limitations whose collection would require highly targeted surveys, the RCGE approach was preferred. Furthermore, the proposed investment would impact more than one area in the South Department and impacts beyond the Project Zone of Influence which would not have been captured with a LEWIE.
} 
Figure 2: Flow of payments in the RCGE

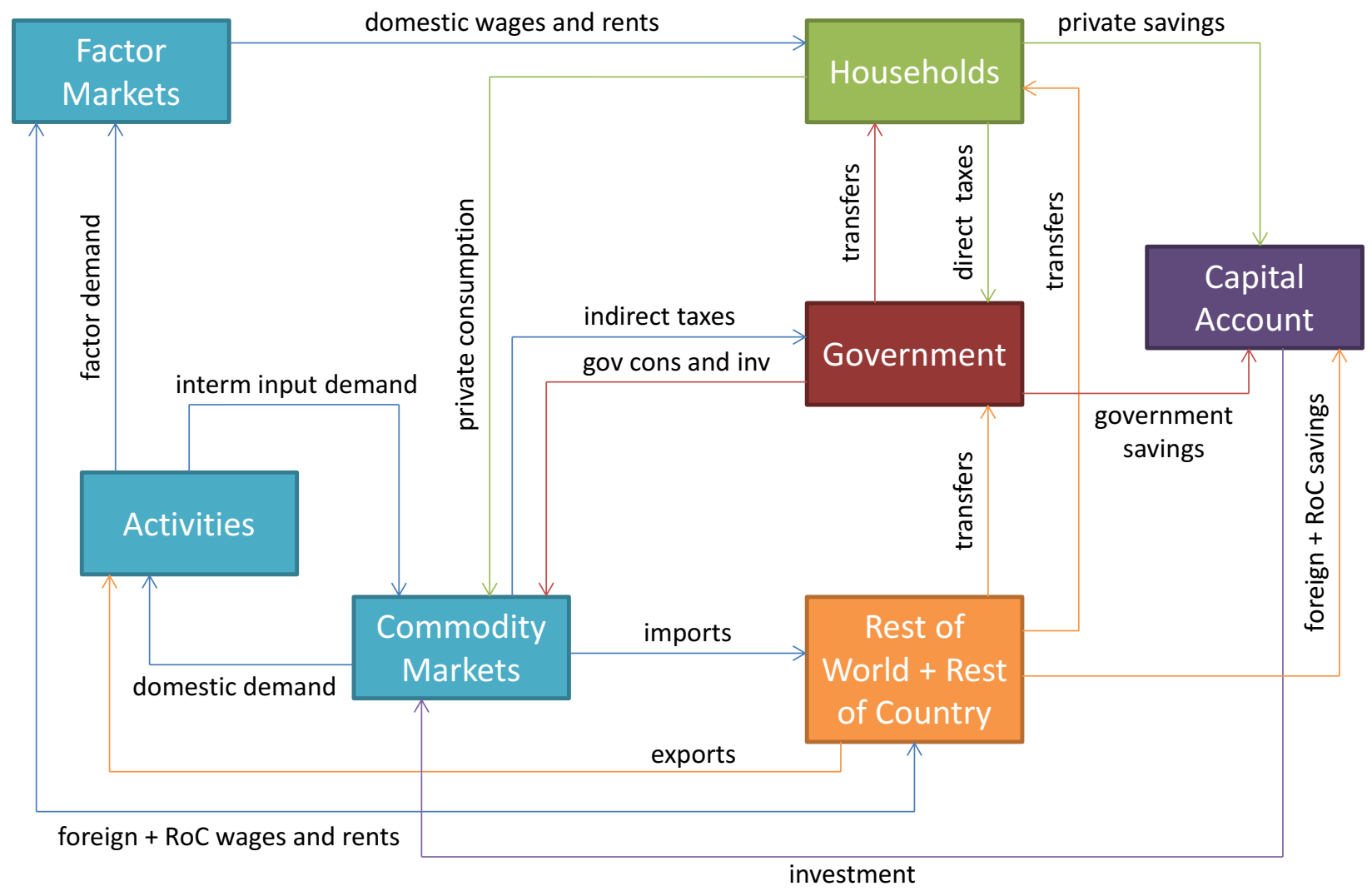

The RCGE model mathematically describes the optimizing behavior of agents in their economic environment; it is a system of equations describing the utility maximizing behavior of consumers, profit maximizing behavior of producers, and the equilibrium conditions and constraints imposed by the macroeconomic environment. Agent behavior is represented by linear and non-linear first order optimality conditions and the economic environment is described as a series of equilibrium constraints for factors, commodities, savings and investment, the government, and rest of the world accounts (Lofgren et al., 2002). The model may be broken into a series of blocks, namely: production, factor markets, institutions, commodity markets, and macroeconomic balances. These model blocks are discussed in turn.

\section{Production}

The model's structure enables a given activity to produce more than one commodity, while any one commodity may be produced by more than one activity. Firms are price takers and minimize costs subject to nested technological constraints. Sectoral output is determined by combining value added with intermediate consumption through a fixed share, Leontief production function. Composite labor is a constant elasticity of substitution (CES) function of various types of labor indicating imperfect substitutability between labor types. Composite capital and land are also formed in this way. Value added is created by a CES function of factors (labor, capital, land and 
other natural resources) where firms employ factors until the value of the factor's marginal product is equal to the factor price.

\section{Income and savings}

Households receive income from labor, capital, land and transfers from other agents including remittances from abroad. Factor income is apportioned to households in fixed shares while income from transfers is the sum of all transfers for each household category. Households pay direct taxes and make transfers to the government, which constitute contributions to social assistance programs such as employment insurance. The government is a consolidated institutional sector; in practical terms, and due to the lack of data, there is only one government which is the sum of central and local governments. Depending on the selected closure rule, government expenditures are exogenous. Disposable household income is equal to household income net of transfers, taxes and savings. Household savings are a linear function of disposable income.

Firms receive income from returns to capital and transfers from other agents. Firms pay income tax and also save. The government receives income from income tax paid by firms and households, indirect taxes on goods and services, capital taxes, import duties, production taxes on industries, payroll taxes from labor, export taxes, and income from transfers.

Income taxes for firms and households are a linear function of their total income. The rest of the world receives income from the sale of imports, returns to capital and transfers, while foreign spending consists of export purchases and transfers to agents in the domestic economy. Transfers to households and firms are treated as exogenous while household transfers to other institutions are treated as a linear function of total income. The treatment of the rest of the country is similar to that of the rest of the world.

\section{Demand}

Goods and services are demanded by households, domestic and foreign tourists, the government, investment, and as transport and trade margins. Households have a Stone-Geary utility function, with a linear expenditure system (LES) describing household consumption. In a LES, households use their income to first consume a minimum level of subsistence goods and services. With the supernumerary income remaining, households purchase goods and services according to a linear relationship between income and consumption. LES functions differ from CES functions in that LES functions have non-unitary income elasticities and non-zero cross-price elasticities between all pairs of goods, which enable flexibility in substitution possibilities in response to changes in relative prices.

Investment demand is composed of gross fixed capital formation (GFCF) and changes in inventories. GFCF is endogenous with total investment expenditure balanced by the savings and investment constraint where savings is endogenous. Inventory changes are exogenous in the 
model and fixed in volume. Investment in goods and services occurs in fixed shares. Government expenditures for a given budget also follow this logic.

Tourism demand for commodities can be exogenous or endogenous. In the current application, it is assumed that foreign tourism demand follows an exogenous path, which allows assessment of the impact of increased foreign tourism demand predicted by the destination-specific tourism demand and value chain analysis. The inflow of foreign tourism is a source of foreign exchange for the South Department.

\section{Supply and trade}

The South Department is too small to affect prices in international and interregional markets and, as a consequence, the RoC and RoW (rest of country and rest of world, respectively) prices are taken to be exogenous. In the tradable goods sectors, the composite commodity price is a weighted average of local prices and import prices (i.e., from RoC and RoW), whereas in most tourism sectors, prices are determined by local average costs. Thus, tourism services produced in the local economy are assumed to be non-tradable.

A constant elasticity of transformation (CET) function describes how industry output responds to changes in prices. This functional form implies that an industry may reorganize production in response to changes in prices, though they cannot perfectly switch from the production of one commodity to another. Industries allocate output to domestic and foreign markets based on the assumption that the goods destined to one market are different from those destined to another market. This assumption is operationalized through a CET function. World export prices are fixed (i.e. the world export demand curve is horizontal). Domestic and imported commodities are aggregated with a CES function. To reflect heterogeneity in goods and services with regards to their origin, goods and services consumed domestically are aggregate goods composed of domestically produced and imported goods, both from the rest the world and the rest of Haiti.

\section{Model dynamics}

In the RCGE, growth over time is largely endogenous. The economy grows due to accumulation of capital determined by investment and depreciation, a growing and increasingly productive labor force determined by exogenously imposed projections, and as a function of improvements in total factor productivity (TFP), which have both endogenous and exogenous components. Apart from the exogenous component, TFP of any productive activity potentially depends, usually positively, on the levels of government capital stocks and economic openness.

On the supply side of the labor markets, unemployment is endogenous: for each labor type, the model includes a wage curve that imposes a negative relationship between the real wage and the unemployment rate (Blanchflower and Oswald, 2004). As will be shown, the economic impacts of an increase in inbound tourism depend critically on the assumptions made about the extent of wage flexibility in the economy. In fact, the effects of tourism growth on economic variables will 
differ depending on the ability of the tourism-related sectors to obtain labor without pushing wages upwards. For non-labor factors, the supply curves are vertical in any single year.

\section{Model dataset}

The basic accounting structure and much of the underlying data required to implement our RCGE model is derived from a Regional Social Accounting Matrix (RSAM) constructed for the South Department. An RSAM is a comprehensive, economy-wide statistical representation of a regional economy at a particular point in time. It is a square matrix with identical row and column accounts where each cell in the matrix shows a payment from its column account to its row account. It is used for descriptive purposes and is the key data input for the RCGE. Major accounts in a standard RSAM are: activities that carry out production; commodities (goods and services) which are produced and/or imported and sold domestically and/or exported; factors used in production which include labor, capital, land and other natural resources; institutions such as households, government, and the rest of the country and the rest of the world. Generally speaking, most features of the RSAM are familiar from social accounting matrices used in other models. The RSAM developed here does, however, have some unconventional features related to the explicit treatment of (i) trade relations (exports and imports) between the South Department and the rest of Haiti, and; (ii) domestic and foreign tourism-related spending.

In this study, the RCGE model was calibrated to a newly-constructed RSAM for fiscal year (FY) 2013 and other data for Haiti and the South Department. The FY 2013 is the latest for which supply and use tables (i.e., the core required data) are available. In addition to the supply and use tables, the main sources of information used in constructing the RSAM were national accounts, balance of payments, government data (specifically, budget and recurrent incomes and expenditures), and income and expenditure household survey data (IHSI, 2003, 2012). ${ }^{3}$ The RSAM was built following the methods and assumptions described by Jackson (1998), Lahr (2001), and Madsen and Jensen-Butler (1999).

Table 1 shows the accounts in the RSAM, which determine the size (i.e., disaggregation) of the model. The RSAM includes 11 sectors producing 11 commodities ${ }^{4}$. The factors of production include four types of labor, unskilled (no education and primary education), semi-skilled (secondary education), and skilled (tertiary education). The non-labor factors include a private capital stock, land, and a natural resource used in mining activities. The RSAM also identifies current accounts for institutions (household, government, rest of Haiti, rest of the world, tourists from Haiti, and tourists from rest of world), two investment accounts, and accounts for national and local taxes.

\footnotetext{
${ }^{3}$ This supply and use tables are believed to be the first update since the original input-output table dating back to 1975/76. To construct the government account of the RSAM, The Central Bank of the Republic of Haiti and the Ministry of Economics and Finance were consulted for balance of payments, and income and expenditure data.

${ }^{4}$ Unfortunately, the available data (i.e., national supply and use tables and regional employment) does not allow us to further disaggregate the tourism-related industries in the RSAM. For example, we have insufficient information to disaggregate the Transport and communications sector into its two sub-sectors.
} 
Table 1: Accounts in the Haiti South region FY 2013 regional social accounting matrix

\begin{tabular}{|c|c|c|c|}
\hline Category & Item & Category & Item \\
\hline \multirow{11}{*}{$\begin{array}{l}\text { Sectors } \\
\text { (activities } \\
\text { and } \\
\text { commodities) } \\
(11)\end{array}$} & Agriculture, forestry and fishing & Factors (7) & Labor, no education \\
\hline & Mining & & Labor, primary education \\
\hline & Manufacturing & & Labor, secondary education \\
\hline & Electricity and water & & Labor, tertiary education \\
\hline & Construction & & Capital \\
\hline & Trade & & Land \\
\hline & Hotels and restaurants & & Extractive natural resources \\
\hline & Transport and communications & \multirow{6}{*}{$\begin{array}{l}\text { Ins titutions } \\
\text { (6) }\end{array}$} & Households \\
\hline & Financial services & & Government \\
\hline & Other market services & & Rest of the world \\
\hline & Other non-market services & & Tourism demand, Rest of the world \\
\hline \multirow[t]{6}{*}{ Taxes } & Activity tax & & Rest of the country \\
\hline & Commodity tax & & Tourism demand, Rest of the country \\
\hline & Commodity subsidy & \multirow{4}{*}{$\begin{array}{l}\text { Savings- } \\
\text { Investment } \\
\text { (4) }\end{array}$} & Savings \\
\hline & Import tariff & & Investment, private \\
\hline & Direct tax & & Investment, government \\
\hline & & & Stock change \\
\hline
\end{tabular}

Source: Authors' own elaboration.

According to our estimates in the RSAM, the South Department's Gross Regional Product (GRP) reached 28,686 million gourdes in FY 2013 (see Table 2), equivalent to 7.8\% of the national Gross Domestic Product (GDP). In FY 2013, the regional government current consumption was $2 \%$ percent of regional GRP. Remittances accounted for $19.2 \%$ of GRP. 
Table 2: GRP structure (million gourdes)

\begin{tabular}{|c|c|c|}
\hline Item & $\mathrm{LCU}$ & GDP Share \\
\hline \multicolumn{3}{|l|}{ Total Demand } \\
\hline Private consumption & $16,604.5$ & 57.9 \\
\hline Fixed investment & $4,834.8$ & 16.9 \\
\hline Stock change & 2.5 & 0.0 \\
\hline Government consumption & 561.0 & 2.0 \\
\hline Exports & $2,045.5$ & 7.1 \\
\hline Exports to RoC & $16,946.7$ & 59.1 \\
\hline Tourism demand RoC & 0.0 & 0.0 \\
\hline Tourism demand RoW & 375.4 & 1.3 \\
\hline Total & $41,370.4$ & 144.2 \\
\hline \multicolumn{3}{|l|}{ Total Supply } \\
\hline GDP at market prices & $28,686.2$ & 100.0 \\
\hline Imports & $8,852.6$ & 30.9 \\
\hline Imports from RoC & $3,831.6$ & 13.4 \\
\hline Total & $41,370.4$ & 144.2 \\
\hline
\end{tabular}

Source: Authors' own elaboration; South Department RSAM.

The production and trade structure of the South Department is reflected in panels (a) and (b) of Table 3, respectively (see Table 3.c for variable definitions). Column EMPshr in Table 3.a shows the share of each sector in total employment. For example, the tourism-related sector of hotels and restaurants represents one percent of total employment. In turn, Columns EXPshr and IMPshr of Table 3.b show the share of each sector in total exports and imports to/from rest of world, respectively. Columns EXP-OUTshr and IMP-DEMshr of Table 3.b present, for each sector, the share of exports to RoW in production and the share of imports from RoW in consumption, respectively. For instance, while the mining sector represents a significant share of export revenue (around $71.4 \%$ ), their share in total value added is only about $4 \%$.

The Haiti South Department FY 2013 SAM reports taxes paid by institutions, commodity sales, activities, and tariffs; estimated total (regional) net tax revenue reached 5.6\% of GRP in FY 2013, compared to $8 \%$ at the national level. In terms of trade with the rest of Haiti, columns (EXP-RoCshr) and (IMP-RoCshr) of Table $3 \mathrm{~b}$ show the share of each sector in total exports and imports to/from the rest of the country, respectively. 
Table 3.a: Sectoral production structure in FY 2013 (percent)

\begin{tabular}{|l|r|r|r|}
\hline Commodity & VAshr & PRDshr & EMPshr \\
\hline Agriculture, forestry and fishing & 30.3 & 33.3 & 58.9 \\
\hline Mining & 0.8 & 0.9 & 1.1 \\
\hline Manufacturing & 4.1 & 7.7 & 3.0 \\
\hline Electricity and water & 1.8 & 2.6 & 0.2 \\
\hline Construction & 23.2 & 18.7 & 2.1 \\
\hline Trade & 26.4 & 22.6 & 22.7 \\
\hline Hotels and restaurants & 0.3 & 0.8 & 0.7 \\
\hline Hotels and restaurants, imports & 0.0 & 0.0 & 0.0 \\
\hline Transport and communications & 7.1 & 6.9 & 0.9 \\
\hline Financial services & 2.1 & 2.1 & 0.2 \\
\hline Other market services & 3.7 & 3.9 & 10.1 \\
\hline Other non-market services & 0.3 & 0.3 & 0.2 \\
\hline Total & 100.0 & 100.0 & 100.0 \\
\hline
\end{tabular}

Table 3.b: Sectoral trade structure in FY 2013 (percent)

\begin{tabular}{|c|c|c|c|c|c|c|c|c|}
\hline Commodity & EXPshr & $\begin{array}{r}\text { EXP- } \\
\text { OUTshr }\end{array}$ & IMPshr & $\begin{array}{r}\text { IMP- } \\
\text { DEMshr }\end{array}$ & $\begin{array}{r}\text { EXP- } \\
\text { RoCshr }\end{array}$ & $\begin{array}{r}\text { EXP- } \\
\text { RoC- } \\
\text { OUTshr }\end{array}$ & $\begin{array}{r}\text { IMP- } \\
\text { RoCshr }\end{array}$ & $\begin{array}{r}\text { IMP- } \\
\text { RoC- } \\
\text { DEMshr } \\
\end{array}$ \\
\hline Agriculture, forestry and fishing & 16.7 & 2.8 & 19.3 & 20.1 & 45.2 & 53.2 & 20.3 & 8.8 \\
\hline Mining & 0.0 & 0.0 & 0.1 & 13.0 & 2.2 & 96.4 & 1.0 & 62.1 \\
\hline Manufacturing & 60.8 & 44.3 & 59.9 & 75.4 & 0.1 & 0.6 & 5.8 & 2.9 \\
\hline Electricity and water & 0.0 & 0.0 & 0.0 & 0.0 & 2.7 & 40.5 & 1.2 & 6.5 \\
\hline Construction & 0.0 & 0.0 & 0.0 & 0.0 & 21.2 & 44.4 & 9.4 & 7.4 \\
\hline Trade & 0.0 & 0.0 & 0.0 & 0.0 & 24.1 & 41.7 & 11.4 & 7.1 \\
\hline Hotels and restaurants & 12.9 & 89.3 & 0.0 & 0.0 & 0.0 & 0.0 & 0.0 & 0.2 \\
\hline Hotels and restaurants, imports & 0.0 & 0.0 & 0.5 & 100.0 & 0.0 & 0.0 & 0.0 & 0.0 \\
\hline Transport and communications & 6.2 & 5.0 & 17.0 & 26.7 & 0.8 & 4.7 & 36.5 & 24.8 \\
\hline Financial services & 1.9 & 5.0 & 2.0 & 21.4 & 1.5 & 27.1 & 0.7 & 3.1 \\
\hline Other market services & 1.4 & 2.0 & 1.2 & 6.9 & 1.9 & 19.3 & 1.0 & 2.4 \\
\hline Other non-market services & 0.0 & 0.0 & 0.0 & 0.0 & 0.3 & 41.1 & 12.8 & 87.5 \\
\hline Total & 100.0 & 5.6 & 100.0 & 25.3 & 100.0 & 39.2 & 100.0 & 25.3 \\
\hline
\end{tabular}


Table 3.c: Variable definitions

\begin{tabular}{|c|c|c|c|}
\hline Variable & Definition & Variable & Definition \\
\hline VAshr & "value-added share (\%) & "IMP-DEMshr & $\begin{array}{l}\text { imports as share of } \\
\text { domestic demand }(\%)\end{array}$ \\
\hline PRDshr & production share $(\%)$ & EXP-RoCshr & $\begin{array}{l}\text { sector share in total } \\
\text { exports to RoC }(\%)\end{array}$ \\
\hline EMPshr & $\begin{array}{l}\text { share in total } \\
\text { employment }(\%)\end{array}$ & EXP-RoC-OUTshr & $\begin{array}{l}\text { exports to RoC as } \\
\text { share in sector output } \\
(\%)\end{array}$ \\
\hline EXPshr & $\begin{array}{l}\text { sector share in total } \\
\text { exports }(\%)\end{array}$ & IMP-RoCshr & $\begin{array}{l}\text { sector share in total } \\
\text { imports from RoC } \\
(\%)\end{array}$ \\
\hline EXP-OUTshr & $\begin{array}{l}\text { exports as share in } \\
\text { sector output }(\%)\end{array}$ & IMP-RoC-DEMshr & $\begin{array}{l}\text { imports from RoC as } \\
\text { share of domestic } \\
\text { demand }(\%)\end{array}$ \\
\hline IMPshr & $\begin{array}{l}\text { sector share in total } \\
\text { imports }(\%)\end{array}$ & & \\
\hline
\end{tabular}

Source: Authors' own elaboration; South region RSAM.

In 2013, foreign tourism spending in the Haiti South Department totaled 375.4 million gourdes (Banerjee, Velasco and Torres, 2014). In turn, according to the RSAM, tourism-induced imports (from the rest of Haiti and the rest of the world) were estimated as 153 million gourdes, or about 41 cents for every gourde of final (foreign) tourism expending in the South department. ${ }^{5}$ The difference between the two figures yields a tourism direct and indirect contribution of 222.4 million gourdes to the South's GRP. The direct tourism contribution to the South's GRP alone was 119.7 million gourdes. In terms of employment, the tourism industry in the South Department of Haiti generates 1,976 and 884 direct and indirect jobs, respectively; thus, total employment in tourism related industries is 2,860 .

Beyond the RSAM, data related to the labor market, depreciation rates for private and public capital, and various elasticities are also used to calibrate the model. These data include number of workers and initial unemployment rates by skill level. The required (exogenous) elasticities include those in production, trade, consumption, and in the wage/rental rate curve. By and large,

\footnotetext{
5 The (direct and indirect) import content of tourism expenditure was estimated using standard input-output techniques (see Smeral, 2006). Certainly, this estimate is influenced by the assumptions made to estimate the domestic use matrix. Specifically, imports in the supply and use tables correspond to a column vector that reports total imports by commodity. Thus, we created an import matrix by pro-rating the totals across uses by applying the structure implied by the total use matrix; that is, for each row of the (total) use matrix we computed the percentage of the row total allocated to each sector. Then, we filled in the import matrix by multiplying each commodity total by the appropriate share for each sector. Finally, we subtracted the new import matrix from the total use matrix to obtain the domestic use matrix.
} 
these data was obtained from the best estimates available from the literature. The robustness of results to variation in these parameters was analyzed with a systematic sensitivity analysis described in detail in Section 4.

\subsection{Microsimulation Model and Data}

While CGE models are effective in capturing aggregate responses to shocks introduced, for example, an increase in tourism demand through improved tourism destination marketing abroad, the standard configuration of a CGE model is not well suited for analysis of questions related to poverty and income inequality. This is due to the fact that most CGE models use a representative household $(\mathrm{RH})$ formulation where all households in an economy are aggregated into one or a few households to represent household and consumer behavior. The main limitation of the RH formulation is that intra-household income distribution does not respond to shocks (e.g. a tourism investment) introduced into the model. Blake et al. (2009) and Wattanakuljarus and Coxhead (2008) are examples of CGE analyses which use the RH approach and explore tourism impacts on poverty and income distribution.

To provide greater resolution with regards to household-level impacts, we generate results in terms of poverty and inequality at the micro level by linking the RCGE model with a microsimulation model (Figure 3). The two models interact in a sequential "top-down" fashion (i.e., without feedback): the RCGE communicates with the microsimulation model by generating a vector of (real) wages ${ }^{6}$, aggregate employment variables such as labor demand by sector and the unemployment rate, and non-labor income. The functioning of the labor market thus plays an important role, and the RCGE model determines the changes in employment by factor type and sector, and changes in factor and product prices that are then used for the microsimulations.

Figure 3: The Macro-Micro approach

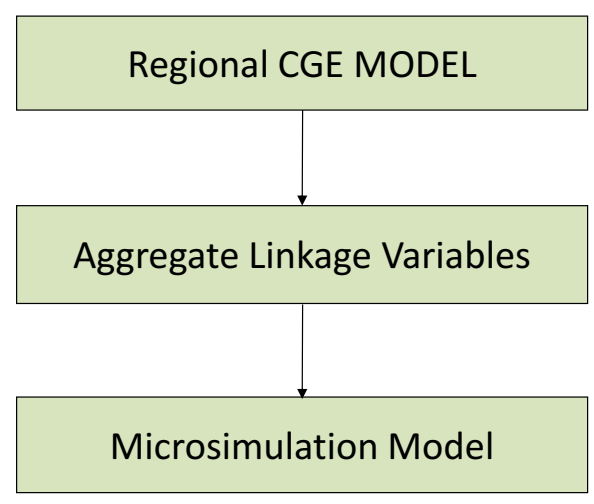

Source: Authors' own elaboration.

\footnotetext{
${ }^{6}$ The real wage is defined in terms of the CPI; see the RCGE model mathematical statement in the Appendix A.
} 
To build the microsimulation model, the household survey Enquête sur les Conditions de Vie des Ménages Après Seisme (ECVMAS) for the year 2012, conducted by the Haitian Institute of Statistics and Informatics (IHSI), was used. These data cover 23,555 individuals in 4,930 households in all of Haiti. The ECVMAS is the latest available household survey in Haiti. No attempt was made to reconcile the household survey data with the national accounts. Instead, the results from the RCGE are transmitted to the microsimulation model as percentage deviations from base values. ${ }^{7}$

The 2012 poverty rates using the poverty line recently estimated by the World Bank (2014) are calculated as $58.64 \%$ poverty and $23.74 \%$ extreme poverty at the national level. In the South Department they are $65.47 \%$ and $25.51 \%$ for poor and extremely poor, respectively.

The microsimulation model follows the non-parametric method described in Vos and Sanchez (2010) but was extended to consider changes in non-labor income. ${ }^{8}$ First, the labor market structure is defined in terms of rates of unemployment $U$ among different segments of the population at working age (in this case, defined according to skill), the structure of employment $S$ (in this case, defined according to sector of activity $S$ ) and (relative) remuneration $W 1$, as well as overall level of remuneration $W 2$. The labor-market structure can thus be written as:

$$
\lambda=(U, S, W 1, W 2),
$$

and the effect of altering each of its four parameters on poverty and inequality can then be analyzed by simulating counterfactual individual earnings and family incomes. Briefly, the model selects at random (with multiple repetitions) from the corresponding labor groups the individuals who will change labor market status (i.e., employment/unemployment and sector) and assigns wages to new workers according to parameters for the average groups. Then, the new wage and employment levels for each individual result in new household per capita incomes that are then used to determine the new poverty and income distribution results. Analytically, we can write:

$$
y l_{i}=f\left(\lambda, X_{i}\right)
$$

where

$$
\begin{aligned}
& y l_{i}=\text { individual labor income } \\
& X_{i}=\text { individual characteristics; e.g., skill level }
\end{aligned}
$$

\footnotetext{
${ }^{7}$ The ECVMAS 2012 was processed as part of the Socio-Economic Database for Latin America and the Caribbean (CEDLAS and The World Bank, 2012); see <http://sedlac.econo.unlp.edu.ar/eng/index.php>.

${ }^{8}$ In turn, this approach is an extension of the earnings inequality method developed by Almeida dos Reis and Paes de Barros (1991).
} 
In each counterfactual scenario, labor market conditions might change and in turn impact the individual labor income; i.e.:

$$
y l_{i}^{*}=f\left(\lambda^{*}, X_{i}\right)
$$

where $\lambda^{*}$ refers to the simulated labor market structure parameters.

The labor market variables and procedures that link the RCGE model with the microsimulations are as follows. This "unemployment effect" is simulated by changing the labor status of the active population in the ECVMAS (2012) sample based on the results from the RCGE model. For instance, if according to the RCGE simulations unemployment decreases at the same time that employment increases for, say, semi-skilled workers in sector A, the microsimulation model "hires" randomly from the ECVMAS sample among the unemployed semi-skilled. As explained above, individual incomes for the newly employed are assigned based on their characteristics (e.g., educational level) by looking at similar individuals that were originally employed. If the RCGE simulations indicate a decrease in employment for a specific labor category and sector, the microsimulation program "fires" the equivalent percentage from the type of labor and sector, and the counterfactual income for those newly unemployed is zero.

The "sectoral structure effect" is simulated by changing the sectoral composition of employment. For those individuals that move from one sector to another, we simulate a counterfactual labor income based on their characteristics and on their new sector of employment, again by looking at individuals that were originally employed in the sector of destination.

To model the change in relative wages, wages for a given labor category (e.g., semi-skilled workers in sector A) are adjusted according to the changes from the RCGE simulations but keeping the aggregate average wage for the economy constant. The impact of the change in the aggregate average wage for the economy is simulated by changing all labor incomes in all sectors, by the same proportion, based on the changes from the RCGE simulations. Next, all the previous steps are repeated several times and averaged.

For non-labor incomes, government transfers and remittances from abroad are proportionally scaled up or down using changes taken from the RCGE model. The final step in the microsimulation model is to adjust the micro data such that the percentage change in the household per capita income matches the change in household per capita income - for each representative household in the RCGE simulations. Thus, this residual effect implicitly accounts for changes in all items not previously considered (i.e., non-labor and non-transfer incomes) such as natural resource and capital rents. 


\section{Simulations and Results}

\subsection{Scenarios}

This section presents the simulations and analyzes the results. The following main scenarios were conducted: (i) the baseline scenario is the scenario without the investment in tourism; (ii) a government investment in tourism infrastructure and strengthening of the South Department's institutions; (iii) an increase in tourism expenditure in the South Department that is expected to result from the government investment, and; (iv) a break-even scenario using the minimum tourism expenditure in the South Department required for the investment to be economically viable. A detailed description follows.

Baseline scenario: this first simulation assumes that (average) past trends will continue from FY 2013 to FY 2040. In fact, in the absence of better projections, it is assumed that Haiti's South Department is on a balanced growth path, which means that real or volume variables, including tourism demand, grow at the same rate while relative prices do not change. The non-base simulations only deviate from the base beginning in FY 2015 to FY 2040.

Invest scenario: this simulation imposes increased government investment in tourism infrastructure and management financed with the investment which is treated as a foreign grant. The yearly additional government investment was allocated as follows:

(a) The total investment is US\$36 million, equivalent to 1,502 million gourdes at base year (i.e., FY 2013) prices ${ }^{9}$;

(b) Forty-four percent of total investment is spent in tourism infrastructure, equivalent to $2.3 \%$ of GRP in the base year ${ }^{10}$;

(c) The remaining 56 percent of the US\$36 million is spent on government current consumption, equivalent to $2.9 \%$ of base year GRP. This represents investment in institutional strengthening and capacity building;

(d) The projected yearly investment disbursement is estimated as $3 \%$ in $2015,15 \%$ in 2016 , $25 \%$ in $2017,25 \%$ percent in 2018 , and $32 \%$ in 2019 ; and

(e) Starting in 2016, an additional 8 percent of total cumulative infrastructure investment is spent on operation and maintenance of the infrastructure.

Demand scenario: in this simulation, foreign tourist arrivals and demand increase. Based on demand projections from Banerjee (2014), it was assumed that due to the tourism investment, foreign tourism demand would increase by $13.8 \%$ annually from 2017 to 2026 and $2.5 \%$

\footnotetext{
${ }^{9}$ In the FY 2013, and according to the RSAM, (local and central) government investment in the Haiti South Department was 593.7 million gourdes.

${ }^{10} 3.4 \%$ of projected GRP for FY 2015.
} 
annually from 2027 to 2040; thus, starting in 2026, foreign tourism arrivals and demand remains $157.4 \%$ higher than in the reference scenario (Banerjee, Velasco and Torres, 2014). More specifically, the increase in tourism leads to an increase in demand for goods and services such as accommodation, food, and transport. ${ }^{11}$

Combination scenario: this scenario models the invest and demand scenarios combined. For details, see Figure 4.

Combination-Break-even scenario: this scenario is similar to combi but uses the estimated minimum growth in tourism expenditure required for the tourism investment to break even at a $12 \%$ discount rate. The break even compound rate of tourism expenditure was estimated at $102.96 \%$. This compound growth rate implies that tourism expenditure in the South Department would need to increase from US\$9 million in the base year to US\$41.71 million by 2040 (Banerjee, Velasco and Torres, 2014). Notice, however, that a constant growth rate for tourism arrivals and demand between 2015 and 2040 is assumed in this scenario.

Figure 4: Definition of scenarios invest and demand (\% deviation from base)

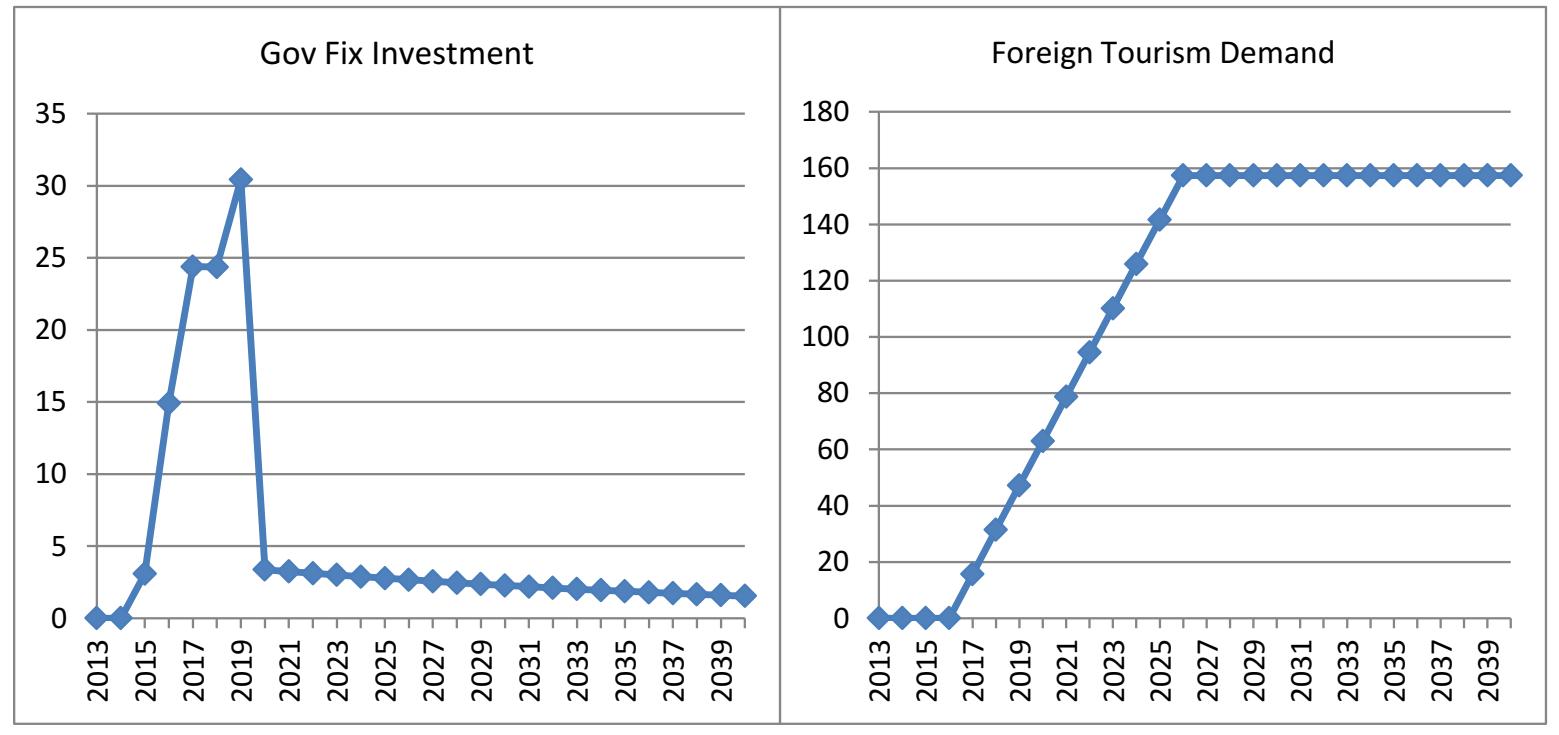

Source: Authors' own elaboration.

At the macro level, our RCGE, as any other CGE model, requires the specification of the equilibrating mechanism for three macroeconomic balances. For the non-base scenarios: (i) the government fiscal account is balanced via adjustments in transfers to/from the $\mathrm{RoC}$ - implicitly representing transfers to/from the central government; (ii) private investment in the South Department follows an exogenously imposed path; given this path, adjustments in savings from the rest of Haiti clear the savings-investment balance; and (iii) the real exchange rate equilibrates

${ }^{11}$ The share of each commodity in total tourism spending was obtained from Banerjee, Velasco and Torres (2014). 
inflows and outflows of foreign exchange, by influencing export and import quantities. The nontrade-related payments of the (local) balance of payments (transfers and foreign investment) are non-clearing, following exogenously imposed paths.

In addition, given the regional character of the model, a mechanism is required to clear the current account of the balance of payments between the local economy and the rest of the country. Specifically, it is assumed that the real exchange rate is flexible with respect to the RoC, with equilibrium achieved through changes in the price of local non-tradable commodities. In other words, prices for non-tradable commodities are region-specific, while for tradable commodities the local price is a weighted average of the price of three different varieties: local, from the RoC, and from the RoW.

\subsection{Results}

\section{Aggregate results}

The base year of the model is FY 2013. For the base scenario, which serves as a benchmark for comparisons, we impose an average growth of 4 percent, based on projections from the April 2014 International Monetary Fund World Economic Outlook (IMF, 2014) ${ }^{12}$. In addition, due to the assumption of a balanced growth path, the following assumptions were also imposed: (i) macro aggregates are kept fixed as a share of regional GRP at base year values; (ii) transfers to/from government/RoC/RoW to households are also kept fixed as a share of GRP, and; (iii) tax rates are fixed over time.

In Table 4 and Figure 5 we show key macroeconomic results for the base and the scenarios for the year 2019 (i.e., the year when the project investment is completed) and 2040. In Table 4, all indicators are for the South Department alone. As the table shows, the increase in government investment financed with the tourism investment has a positive impact on the activity level (simulation invest). On the other hand, the inflow of foreign resources gives rise to slower export growth and faster import growth, both of which were induced by an appreciation of the regional real exchange rate. ${ }^{13}$ In turn, the expansion of tourism demand tends to expand domestic absorption more rapidly than it expands GRP, also causing deterioration in the trade balance (scenario dem). In other words, the increase in "tourism exports" also generates an appreciation of the real exchange rate that hurts the tradable sectors. Besides, slower export growth here is a function of increasing domestic demand and prices in the South Department due to the investment. Where factor supply constraints exist (labor/capital/land/natural resources), increased domestic prices relative to world prices result in a reallocation of resources toward domestic production and meeting more rapid growth in domestic demand.

\footnotetext{
${ }^{12}$ The exogenous part of total factor productivity growth is adjusted to generate such a growth path. In non-base scenarios, GRP growth is endogenous.

${ }^{13}$ Notice that "exports" do not include tourism-related spending made by foreigners. Certainly, the latest correspond to tourism exports, but the two are treated differently in the model and Table 4.
} 
Figure 5.a: Change in real private consumption 2014-2040 (percent deviation from base)

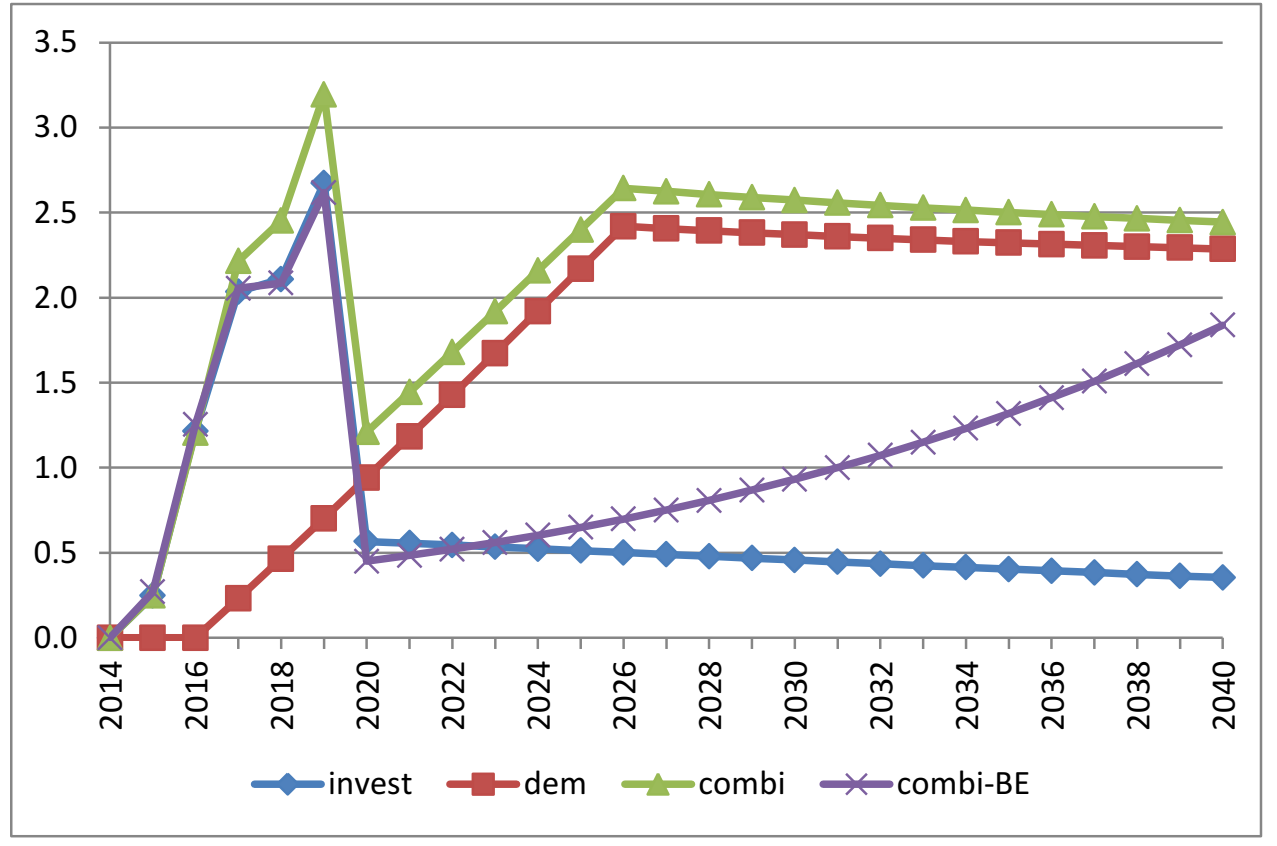

Figure 5.b: Change in real gross regional product 2014-2040 (percent deviation from base)

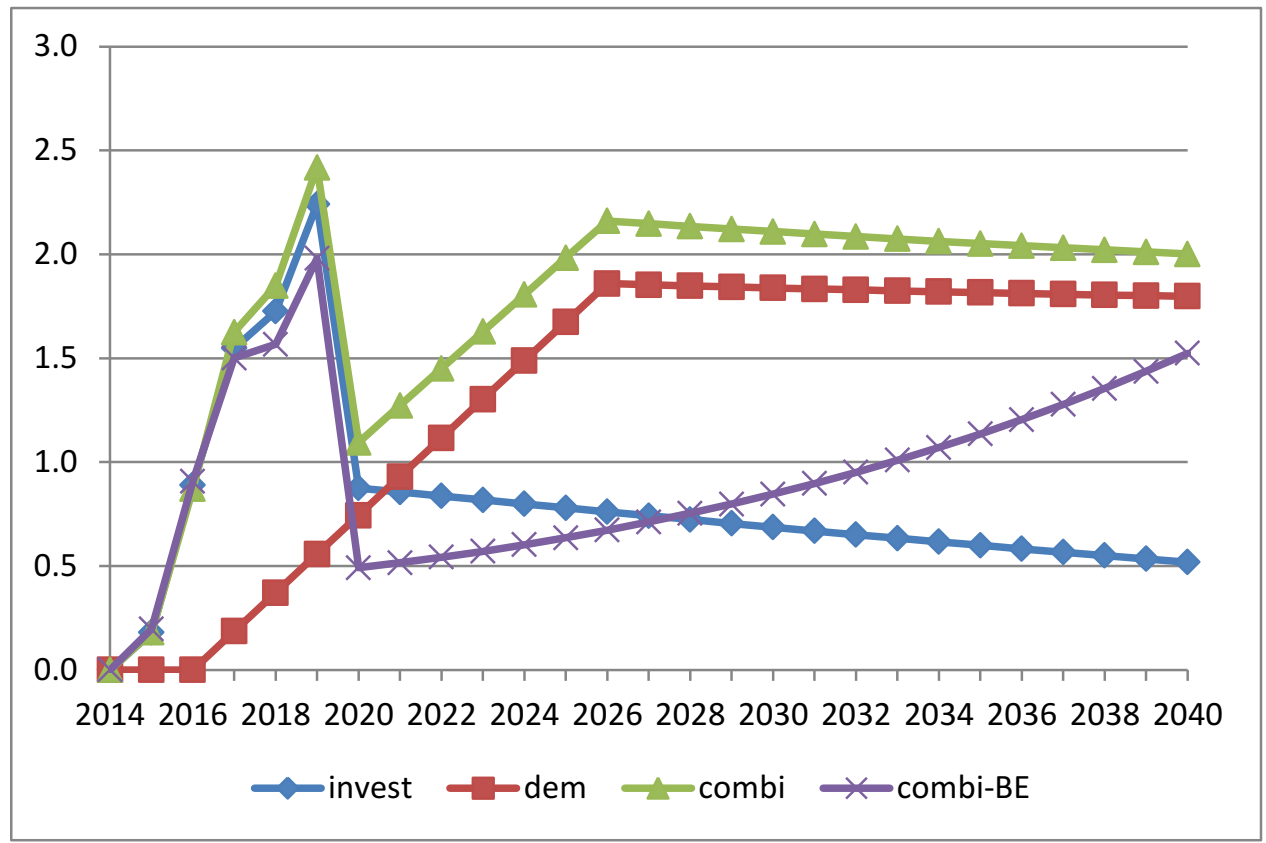

Source: Authors' own elaboration. 
Table 4: Change in real macro indicators (percent deviation from base)

\begin{tabular}{|l|r|r|r|r|r|r|r|r|r|}
\hline & base (LCU) & invest & dem & combi & combi-BE \\
\hline Item & 2013 & 2019 & 2040 & 2019 & 2040 & 2019 & 2040 & 2019 & 2040 \\
\hline Absorption & 35,493 & 2.9 & 0.4 & 1.0 & 3.3 & 3.6 & 3.4 & 2.8 & 2.5 \\
\hline Private consumption & 16,605 & 2.7 & 0.4 & 0.7 & 2.3 & 3.2 & 2.4 & 2.6 & 1.8 \\
\hline Government consumption & 561 & 40.5 & 1.6 & 0.0 & 0.0 & 40.5 & 1.6 & 40.5 & 1.6 \\
\hline Exports to rest of world & 2,045 & -2.5 & 1.1 & -1.5 & -5.1 & -4.7 & -4.7 & -3.6 & -3.3 \\
\hline Imports from rest of world & 8,853 & 3.8 & 0.3 & 1.9 & 6.0 & 5.5 & 6.1 & 3.9 & 4.5 \\
\hline Exports to rest of Haiti & 16,947 & 2.4 & 0.5 & 0.4 & 1.3 & 2.3 & 1.5 & 2.0 & 1.1 \\
\hline Imports from rest of Haiti & 3,832 & 6.1 & 0.5 & 0.3 & 1.1 & 6.1 & 1.4 & 5.8 & 1.0 \\
\hline GRP at market prices & 28,686 & 2.2 & 0.5 & 0.6 & 1.8 & 2.4 & 2.0 & 2.0 & 1.5 \\
\hline RER wrt rest of world & 1 & -2.9 & 0.3 & -1.4 & -4.2 & -4.5 & -4.1 & -3.4 & -3.0 \\
\hline RER wrt rest of Haiti & 1 & 0.3 & 0.1 & 0.0 & 0.1 & 0.3 & 0.1 & 0.3 & 0.1 \\
\hline Wage, average & 1 & 0.8 & 0.1 & 0.4 & 1.2 & 1.1 & 1.2 & 0.8 & 0.9 \\
\hline Capital return, average & 1 & 2.1 & 0.4 & 0.5 & 1.6 & 2.3 & 1.7 & 1.9 & 1.3 \\
\hline Unemployment rate & 26 & 24.4 & 25.8 & 25.2 & 23.4 & 23.7 & 23.4 & 24.3 & 24.0 \\
\hline
\end{tabular}

$\mathrm{LCU}=$ million gourdes

Source: Authors' own elaboration.

Sectoral results

At the sectoral level, service industries catering directly to tourists, including Hotels and restaurants, are strongly stimulated by the expansion in tourism (simulation dem). On the other hand, the upward pressure on prices and the real exchange rate leads to reduced competitiveness of traditional export sectors. Specifically, Table 5 shows a decrease in value added in Agriculture, forestry and fishing, and Manufacturing. To some extent, this result changes when labor and capital are in greater supply (i.e., more elastic supply curves). In other words, if wage increases are constrained and extra labor used would otherwise have been unemployed, these types of crowding out effects are less substantial. 
Table 5: Change in sectoral real value added, exports, and imports (percent deviation from base)

\begin{tabular}{|c|c|c|c|c|c|c|c|c|c|}
\hline & base (LCU) & invest & & dem & & combi & & \multicolumn{2}{|l|}{ combi-BE } \\
\hline Commodity & 2013 & 2019 & 2040 & 2019 & 2040 & 2019 & 2040 & 2019 & 2040 \\
\hline \multicolumn{10}{|l|}{ Value Added } \\
\hline Agriculture, forestry and fishing & 8,325 & 0.9 & 0.4 & 0.1 & 0.3 & 0.5 & 0.3 & 0.5 & 0.2 \\
\hline Mining & 213 & 0.9 & 0.4 & 0.1 & 0.6 & 0.6 & 0.6 & 0.5 & 0.4 \\
\hline Manufacturing & 1,114 & -0.6 & 0.9 & -0.4 & -1.6 & -1.6 & -1.3 & -1.3 & -0.8 \\
\hline Electricity and water & 487 & 1.8 & 0.5 & 0.5 & 2.0 & 1.9 & 2.2 & 1.5 & 1.5 \\
\hline Construction & 6,393 & 2.5 & 0.4 & 0.2 & 0.2 & 2.3 & 0.3 & 2.1 & 0.4 \\
\hline Trade & 7,261 & 3.5 & 0.7 & 0.9 & 3.0 & 3.9 & 3.3 & 3.2 & 2.4 \\
\hline Hotels and restaurants & 87 & 0.9 & 0.1 & 42.0 & 140.4 & 42.9 & 140.5 & 9.4 & 101.3 \\
\hline Transport and communications & 1,940 & 2.3 & 0.6 & 0.6 & 1.9 & 3.2 & 2.7 & 2.8 & 2.2 \\
\hline Financial services & 576 & 2.9 & 0.8 & 0.5 & 1.5 & 2.9 & 1.9 & 2.5 & 1.5 \\
\hline Other market services & 1,014 & 2.2 & 0.6 & 1.1 & 4.8 & 3.6 & 5.5 & 2.8 & 3.8 \\
\hline Other non-market services & 87 & 37.9 & 2.9 & 1.0 & 4.4 & 38.0 & 6.6 & 37.0 & 5.0 \\
\hline \multicolumn{10}{|l|}{ Exports } \\
\hline Agriculture, forestry and fishing & 405 & -3.0 & 0.7 & -1.6 & -5.0 & -5.2 & -4.8 & -4.0 & -3.6 \\
\hline Manufacturing & 1,473 & -2.6 & 1.3 & -1.5 & -5.3 & -5.0 & -5.0 & -3.9 & -3.5 \\
\hline \multicolumn{10}{|l|}{ Imports } \\
\hline Agriculture, forestry and fishing & 1,711 & 3.7 & 0.2 & 1.5 & 4.7 & 5.0 & 4.6 & 3.8 & 3.4 \\
\hline Manufacturing & 5,301 & 3.6 & 0.3 & 2.0 & 6.5 & 5.5 & 6.6 & 3.9 & 4.9 \\
\hline
\end{tabular}

$\mathrm{LCU}=$ million gourdes

Source: Authors' own elaboration.

Certainly, the key mechanisms which determine the size of the economic impacts resulting from increased tourism demand include: factor supply constraints, exchange rate appreciation, and current government economic policy (Dwyer et al., 2000).

In terms of sectoral employment, results are shown in Table 6. As expected, changes in sectoral employment follow those of sectoral value added. 
Table 6: Change in sectoral employment (percent deviation from base)

\begin{tabular}{|l|r|r|r|r|r|r|r|r|r|}
\hline & base ('000) & invest & dem & combi & combi-BE \\
\hline Sector & 2013 & 2019 & 2040 & 2019 & 2040 & 2019 & 2040 & 2019 & 2040 \\
\hline Agriculture, forestry and fishing & 145.1 & 0.8 & 0.1 & 0.2 & 0.6 & 0.9 & 0.6 & 0.8 & 0.5 \\
\hline Mining & 2.6 & 1.1 & 0.1 & 0.2 & 1.0 & 1.2 & 1.0 & 1.1 & 0.7 \\
\hline Manufacturing & 7.4 & -1.2 & 0.9 & -0.6 & -1.2 & -2.1 & -0.8 & -1.8 & -0.7 \\
\hline Electricity and water & 0.4 & 4.3 & 0.5 & 1.5 & 4.6 & 5.7 & 4.9 & 4.5 & 3.8 \\
\hline Construction & 5.2 & 5.5 & 0.2 & 0.6 & 1.9 & 6.1 & 2.0 & 5.6 & 1.6 \\
\hline Trade & 56.0 & 4.6 & 0.6 & 1.3 & 4.4 & 5.7 & 4.7 & 4.7 & 3.5 \\
\hline Hotels and restaurants & 1.7 & 0.9 & 0.0 & 68.7 & 183.9 & 68.1 & 182.1 & 13.2 & 148.3 \\
\hline Transport and communications & 2.0 & 3.3 & 0.5 & 1.0 & 3.4 & 3.9 & 3.6 & 3.1 & 2.6 \\
\hline Financial services & 0.4 & 3.1 & 0.6 & 0.6 & 2.1 & 3.6 & 2.6 & 3.1 & 1.9 \\
\hline Other market services & 25.0 & 4.7 & 0.5 & 2.8 & 8.2 & 6.8 & 8.1 & 4.5 & 6.2 \\
\hline Other non-market services & 0.6 & 41.5 & 2.5 & 1.1 & 4.8 & 42.2 & 6.8 & 41.1 & 5.2 \\
\hline Total & 246.5 & 2.3 & 0.3 & 1.2 & 3.5 & 3.2 & 3.6 & 2.3 & 2.8 \\
\hline
\end{tabular}

Source: Authors' own elaboration.

\section{Distributive results}

In terms of poverty, our results show, for example, that the poverty headcount ratio in the South Department falls by 1.6 percentage points in the last year of the simulation period in the combi scenario (figure 6). The main drivers of this result are a decrease in unemployment, a higher average wage, and an increase in non-labor income. In terms of inequality, we find a slight increase driven by the decrease in the unemployment rate and the change in the sectoral structure of employment in favor of the services sector.

Figure 6: Change in poverty (percentage points from base)

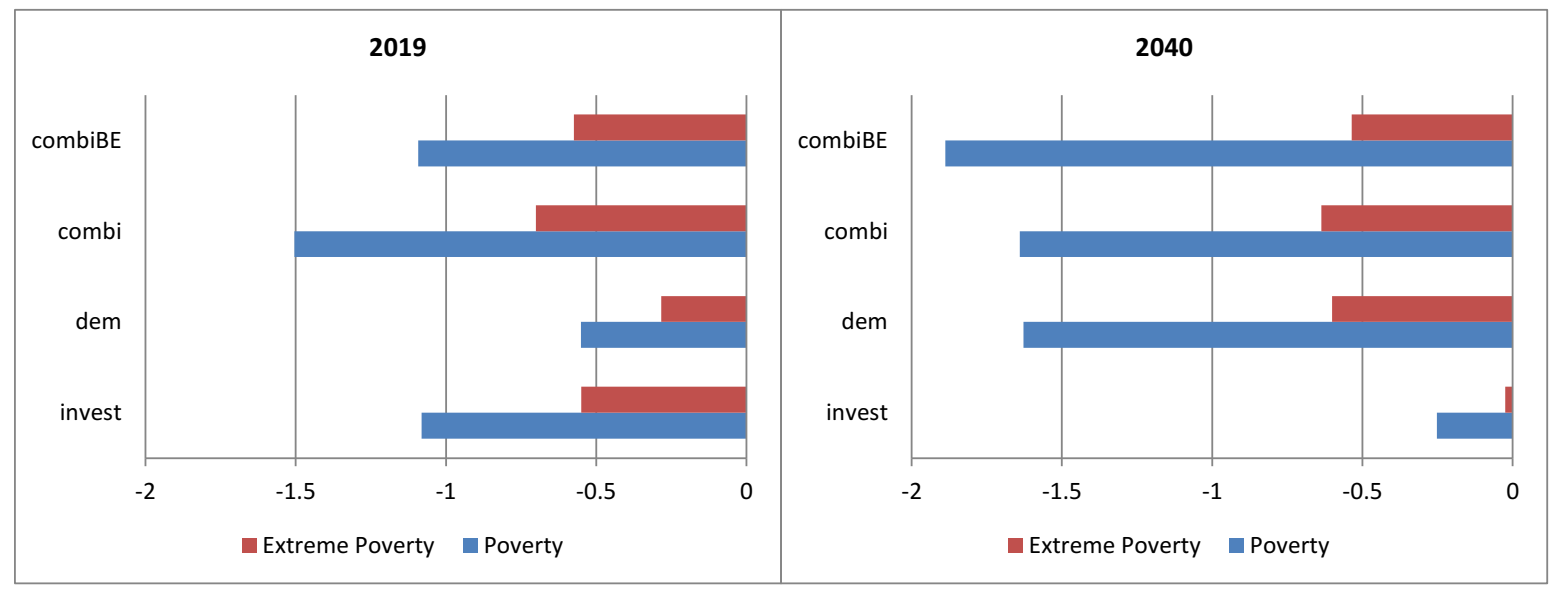

Source: Authors' own elaboration. 


\section{Sensitivity analysis}

As usual, the results from the RCGE model are a function of (i) the model structure (e.g., functional forms used to model production and consumption decisions, macroeconomic closure rule, among other elements); (ii) the base year data used for model calibration (i.e., the RSAM), and; (iii) the values assigned to the model elasticities or, more generally, to the model's free parameters.

Certainly, the elasticities used in this study implicitly carry an estimation error, as in any similar model. Consequently, we have performed a systematic sensitivity analysis of the results with respect to the value assigned to the model elasticities. Hence, if the conclusions of the analysis are robust to changes in the set of elasticities used for model calibration, we will have greater confidence in the results presented above.

In order to perform the systematic sensitivity analysis, it is assumed that each of the model elasticities is uniformly distributed around the central value used to obtain the results. The range of variation allowed for each elasticity is $+/-80 \%$; that is, a wide range of variation for each model elasticity is considered. Then, a variant of the method originally proposed by Harrison and Vinod (1992) is implemented, which allows for performing a systematic sensitivity analysis. In short, the aim is to solve the model iteratively with different sets of elasticities. Thus, a distribution of results is obtained to build confidence intervals for each of the model results. The steps for implementing the systematic sensitivity analysis are as follows.

Step 1. In the first step, the distribution (i.e., lower and upper bound) for each of the model parameter that will be modified as part of the systematic sensitivity analysis is computed: elasticities of substitution between primary factor of production, trade-related elasticities, expenditure elasticities, and unemployment elasticities for the wage curves.

Step 2. In the second step, the model is solved repeatedly, each time employing a different set of elasticities; it is, therefore, a Monte Carlo type of simulation. First, the value for each model elasticity is randomly selected. Second, the model is calibrated using the selected elasticities. Third, the same counterfactual scenarios as previously described are conducted. Then, the preceding steps are repeated several times, 500 in this case, with sampling with replacement for the value assigned to the elasticities.

Table C.1 shows the percentage change in private consumption estimated (i) under the central elasticities, and; (ii) as the average of the 500 observations generated by the sensitivity analysis. For the second case, the upper and lower bounds under the normality assumption were also computed; notice that all runs from the Monte Carlo experiment receive the same weight. As can be seen, the results reported above are significant, while estimates presented in Table 4 are within the confidence intervals reported in Table C.1. For example, there is virtual certainty that the combi scenario has a positive effect on private consumption in the South Department of Haiti. 
Table C.1: Sensitivity analysis; real private consumption percent deviation from base; year 2040 $95 \%$ confidence interval under normality assumption

\begin{tabular}{|l|r|r|r|r|r|}
\hline Scenario & $\begin{array}{r}\text { Central } \\
\text { Elast }\end{array}$ & Mean & $\begin{array}{r}\text { Standard } \\
\text { Dev }\end{array}$ & $\begin{array}{r}\text { Lower } \\
\text { Bound }\end{array}$ & $\begin{array}{r}\text { Upper } \\
\text { Bound }\end{array}$ \\
\hline invest & 0.3542 & 0.3476 & 0.0285 & 0.2918 & 0.4034 \\
\hline dem & 2.2866 & 2.3331 & 0.3525 & 1.6422 & 3.0239 \\
\hline combi & 2.4438 & 2.4838 & 0.3450 & 1.8076 & 3.1601 \\
\hline combi-BE & 1.8379 & 1.8771 & 0.2414 & 1.4039 & 2.3504 \\
\hline
\end{tabular}

Source: Authors' own elaboration.

Figure 7 shows non-parametric estimates of the density function for the percentage change in 2040 in private consumption in the combi scenario. Again, the sign of the results (i.e., positive) is not changed when model elasticities are allowed to differ in $+/-80 \%$ of their "central" value.

Figure 7: Sensitivity analysis, real private consumption deviation from base in 2040

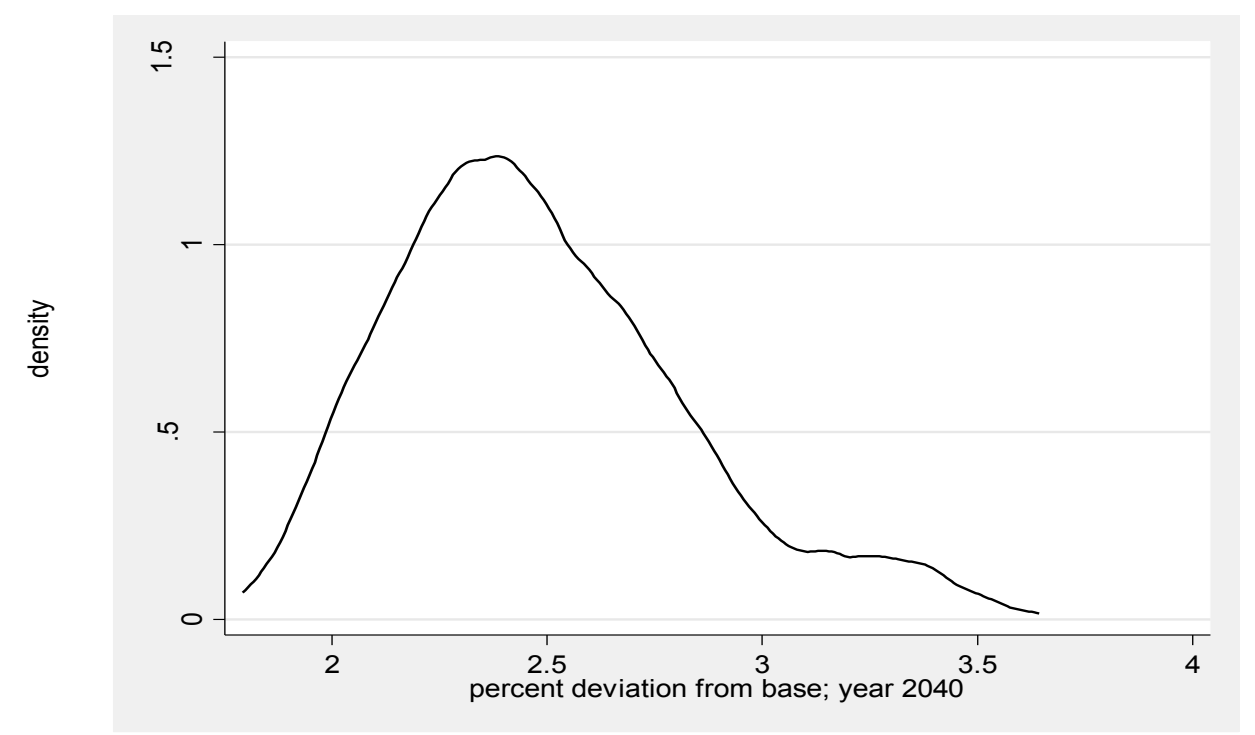

\section{Cost-Benefit Analysis}

As discussed, the results of the combi scenario represent the direct and indirect economic impact of an increase in investment in tourism infrastructure combined with an increase in inbound tourism, given the model assumptions. Thus, given that the project cost is part of the simulations, a cost-benefit analysis can be conducted by simply analyzing the RCGE-MS results for the indicator of interest which is GRP. In other words, the simulated direct and indirect impacts using the RCGE-MS model provide the benefit and cost estimates for this calculation. Notice, 
however, that conventional cost-benefit accounting does not capture all of the indirect benefits highlighted by simulations using economy-wide models. Analytically:

$$
N P V=\sum_{t=0}^{25} \frac{Y_{t}-Y_{t}^{0}}{(1+r)^{t}}
$$

where

$$
\begin{aligned}
& N P V=\text { net present value } \\
& t=0 \text { is } 2015 \\
& t=25 \text { is } 2040 \\
& Y_{t}=\text { indicator of interest in year } \mathrm{t} \\
& Y_{t}^{0}=\text { indicator of interest in year } \mathrm{t} \text { in reference scenario } \\
& r=\text { discount rate }(12 \% \text { in our case })
\end{aligned}
$$

Table 7: net present value, millions of gourdes

\begin{tabular}{|l|r|r|}
\hline Scenario & RCGE & RCGE - invest \\
\hline invest & 3,051 & 1,783 \\
\hline dem & 3,475 & 2,208 \\
\hline combi & 5,421 & 4,154 \\
\hline combi-BE & 3,042 & 1,775 \\
\hline
\end{tabular}

Table 7 shows that in the combi scenario, the NPV for the investment is 5,421 million gourdes. Although the investment is a grant, if the Government of Haiti were required to repay the investment, the NPV declines to 4,154 million gourdes.

\section{Discussion and Policy Implications}

In this paper, a consistent and quantitative framework was developed for the assessment of investment in tourism development and its impacts on regional economies and household welfare. This research addressed three key gaps identified in the tourism impact assessment literature. First, a destination-specific tourism demand and value chain analysis was used to calibrate the simulations. Second, the RCGE-MS approach enabled the analysis of tourism investment impacts on poverty and income inequality indicators at the level of the individual households sampled. Third, modelling results generated here could be used in further cost- 
benefit analysis to assess trade-offs between investment alternatives. The analytical power of this framework derives from its ability to capture inter-sectoral dynamics, the impacts of factor constraints, interactions between the regions modelled, the rest of the country and the rest of the world, and household-level income and poverty indices.

This framework was applied to simulate the impacts of a US\$36 million investment in tourism in Haiti's South Department, considering the impacts of increased local economic activity arising from the improvement of public spaces, facilities and services, institutional strengthening, and an increase in tourism expenditure arising from the intervention. While the investment resulted in a positive impact on local activity, there was a slowing of export growth and faster import growth, both induced by the appreciation of the regional real exchange rate. The expansion of tourism demand leads to domestic absorption increasing more rapidly than the regional product which results in a deterioration of the regional trade balance. The increase in domestic prices results in the reallocation of scarce factors toward domestic production to meet increased tourist demand.

At the sectoral level, those sectors catering more directly to tourism experience the highest rates of growth, while those sectors further removed from the tourism value chain grow more slowly. Assumptions around the scarcity of skilled labor drive the magnitudes of these aforementioned effects. The cost benefit analysis shows that the investment is viable with a $12 \%$ discount rate when treated as a non-reimbursable grant as well as a reimbursable loan, thus lending support to the business case for the investment.

Results at the household level show that the investment reduced the poverty headcount rate in the South Department by 1.6 percentage points. This result was driven by the decrease in unemployment, higher average wages and increased non-labor income accruing to households. In the first few years of the intervention, it is the investment stimulus itself that has the greatest impact on spurring growth and reducing poverty. Employment in construction and related sectors drives average wages upward and has a positive impact on household income. As all works are installed within 5 years of the investment commencing, it is the expected increase in tourism demand that has a larger and more sustained positive impact on local economic development, employment and welfare. The sensitivity analysis confirms that the results reported here are robust to significant variability in model parameters.

This work raises three key issues for the analysis of tourism investments. First, estimating with and without program tourist demand is a critical input into the analysis. Investment in developing the tourism product and the direct, indirect and induced benefits that this generates is one aspect of the growth stimulus. As demonstrated in this analysis, the larger and more sustained stimulus occurs through the increase in tourism expenditure. The estimation of this with program demand is a critical element of the analysis, and is often overlooked or improperly formulated in tourism impact assessments. For the overall investment analysis to be as robust as possible, it is necessary to approximate to the extent possible how tourism demand will respond to the specific 
features of the tourism product that the investment aims to establish or enhance. Modelling results are highly sensitive to variations around with program tourism demand estimates.

Second, a country or region's capacity to absorb public sector funding of this magnitude and implement the investment program efficiently and effectively is a critical element of success. This poses challenges to States with new or weak institutions governing tourism. These features of institutional capacity and absorptive capabilities, although not modelled here, are amenable to simulation in the RCGE-MS framework through the imposition of conversion coefficients or lags in the period over which the investment program is implemented and the economic response is generated.

Third, in considering the long-run sustainability of the investment in public tourism goods and services, the private sector response is a critical determinant. The simulations presented here show the minimum private sector response to increased demand for goods and services arising from the investment in infrastructure as well as increased future tourism demand for goods and services. The private sector has the potential to enhance the overall growth and welfare impact of the investment through hedging toward increased tourism growth and a virtuous cycle of public and private investment and tourism expansion. To achieve this end, some degree of risk will need to be assumed by the private sector. Through public private partnerships, however, a shared agenda between the public and private sector may be forged while the public sector may lend support through reducing some of the risks involved in bold and greenfield investments.

Finally, the framework presented here has the potential to be used as a tool to assess investment alternatives as an integral component of tourism investment design. This is particularly appropriate where the data exists to permit the development of a model with a high degree of disaggregation of those sectors most closely participating in the tourism value chain, and; household survey data are representative of the population in the tourism program Zone of Influence. Where program objectives are clearly defined, such as maximizing regional growth or reducing poverty, the simulation of alternative investments can help in identifying the most efficient and effective pathways. This would be an improvement over the status quo where modeling results are often used in the final stages of program development to confirm that the investment at least breaks even at a given discount rate. 


\section{References}

Banerjee, O. (2014). Baseline and Projected Tourism Demand for Haiti's South Department. In HA-L1095 ANNEX. Washington DC: Inter-American Development Bank.

Annabi, N., Cockburn, J., \& Decaluwé, B. (2006). Functional Forms and Parameterization of CGE Models. Retrieved September 2014 from http://portal.pepnet.org/documents/download/id/13525.

Armitt, T., Ashley, C., \& Goodwin, H. (2014). Inclusive Tourism in Southern Haiti, Analysis of the Current Value Chain; Review of International Good Practice; Action Plan for Inclusive Tourism. Twickenham: Ashley Insight.

Ashley, C., Mitchell, J., \& Spenceley, A. (2009). How to Assess the Potential of a Viable Inclusive Tourism Intervention? Geneva: ITC.

Banerjee, O, Velasco, M. \& Torres, J.C. (2014). Baseline and Projected Tourism Demand for Haiti's South Department. HA-L1095 ANNEX. Washington DC: Inter-American Development Bank.

Banerjee, O. (2014). Investing in Recovering Water for the Environment in Australia's MurrayDarling Basin. International Journal of Water Resources Development. Early view version: http:/www.tandfonline.com/doi/full/10.1080/07900627.2014.979398\#.VH4vf_nF-VM

Banerjee, O., Gachot, S., Lemay, M., \& Jacquet, B. (2014). Monitoring and Ex-Post Economic Impact Evaluation Plan, HA-L1095 ANNEX. Washington DC: Inter-American Development Bank.

Blake, A., Arbache, J. S., Sinclair, M. T., \& Teles, V. K. (2009). Tourism and Poverty Relief. Sao Paulo: FGV. Blanchflower, D. G., \& Oswald, A. J. (2004). Well-Being Over Time in Britain and the USA. Journal of Public Economics, 88(7-8, Jul), 1359-1386.

Buiter, W. H. (1976). Crowding Out and the Effectiveness of Fiscal Policy. Princeton: Princeton University.

CEDLAS and The World Bank. (2012). A Guide to the SEDLAC: Socio-Economic Database for Latin America and the Caribbean. Buenos Aires: Centro de Estudios Distributivos, Laborales y Sociales at Universidad Nacional de la Plata.

Cicowiez, M. (2012). El Enfoque Macro-Micro Aplicado a Cuestiones de Desarrollo Económico Local. Washington D.C.: Inter-American Development Bank, Office of Evaluation and Oversight. 
Decaluwé, B., Lemelin, A., Robichaud, V., \& Maisonnave, H. (2010). The PEP Standard Computable General Equilibrium Model Single-Country, Recursive Dynamic Version, PEP-1-t. Retrieved September 2014 from http://www.pep-net.org/programs/mpia/pepstandard-cge-models/pep-1-t-single-country-recursive-dynamic-version/.

Dwyer, L., Forsyth, P., \& Spurr, R. (2003). Inter-Industry Effects of Tourism Growth: Implications for Destination Managers. Tourism Economics, 9(2).

Dwyer, L., Forsyth, P., \& Spurr, R. (2004). Evaluating Tourism's Economic Effects: New and Old Approaches. Tourism Management, 25(3), 307-317.

Dwyer, L., Forsyth, P., Madden, J., \& Spurr, R. (2000). Economic Impacts of Inbound Tourism under Different Assumptions Regarding the Macroeconomy. Current Issues in Tourism, 3(4), 325-363. doi: 10.1080/13683500008667877

Ferreira Filho, J., \& Horridge, M. J. (2006). Economic Integration, Poverty and Regional Inequality in Brazil. $R B E, 60(4), 363-387$.

Gretton, P. (2013). On Input-Output Tables: Uses and Abuses. Canberra: Productivity $\begin{array}{llll}\text { Commission. } & \text { Retrieved } & \text { September } & 2014\end{array}$ http://papers.ssrn.com/sol3/papers.cfm?abstract id=897758.

Humphrey, J. (2005). Shaping Value Chains for Development: Global Value Chains in Agribusiness. Eschborn: GTZ.

Humphrey, J., \& Schmitz, H. (2000). Governance and Upgrading: Linking Industrial Cluster and Global Value Chain Research. Brighton: IDS.

IHSI. (2003). Enquete sur les Conditions de Vie en Haiti (ECVH). Port-au-Prince: 1'Institut Haïtien de Statistique et d'Informatique.

IHSI. (2012). Enquete sur les Conditions de Vie des Menages Apres Seisme. Port-au-Prince: IHSI.

IMF. (2014). World Economic Outlook World Economic and Financial Surveys. Washington DC: IMF.

Jackson, R. (1998). Regionalizing National Commodity-by-Industry Accounts. Economic Systems Research, 10(3), 223-238.

Klytchnikova, I., \& Dorosh, P. (2012). Tourism Sector in Panama, Regional Economic Impacts and the Potential to Benefit the Poor. Washington DC: The World Bank.

Lahr, M. (2001). Reconciling Domestication Techniques, the Notion of Re-Exports, and Some Comments on Regional Accounting. Economic Systems Research, 13(2), 165-179. 
Madsen, B. and Jensen-Butler, C. (1999). Make and Use Approaches to Regional and Interregional Accounts and Models. Economics Systems Research, 11(3), 277-299.

Mitchell, J., \& Ashley, C. (2009). Value Chain Analysis and Poverty Reduction at Scale, Evidence from Tourism is Shifting Mindsets. London: Overseas Development Institute.

Savard, L. (2003). Poverty and Income Distribution in a CGE-Household Micro-Simulation Model: Top-Down/Bottom Up Approach. Dakar: International Development Research Centre.

Savard, L. (2005). Poverty and Inequality Analysis within a CGE Framework: A Comparative Analysis of the Representative Agent and Microsimulation Approaches. Development Policy Review, 23(3), 313-331. doi: 10.1111/j.1467-7679.2005.00289.x

Taylor, J. E., \& Filipski, M. J. (2014). Beyond Experiments in Development Economics: Local Economy-wide Impact Evaluation. Oxford: Oxford University Press.

Trevelyan, L. (2013). Haiti Tries to Boost its Tourism Industry. BBC News. Retrieved from http://www.bbc.co.uk/news/world-latin-america-23035402

Vanhove, N. (2005). The Economics of Tourism Destinations. Oxford: Elsevier.

Vos, R., \& Sanchez, M. (2010). A Non-Parametric Microsimulation Approach to Assess Changes in Inequality and Poverty. International Journal of Microsimulation, 3(1), 8-23.

Wattanakuljarus, A., \& Coxhead, I. (2008). Is tourism-based development good for the poor? Journal of Policy Modeling, 30(6), 929-955. doi: 10.1016/j.jpolmod.2008.02.006.

WTTC. (2014). Travel \& Tourism Economic Impact 2014 Haiti. London: World Travel and Tourism Council. 


\section{Appendix A: Mathematical Statement of RCGE Model}

\section{A.1. Introduction}

The mathematical presentation of the RCGE uses some notational conventions: capital letters for endogenous variables, lowercase letters for exogenous variables, and Greek letters for behavioral parameters. The endogenous variables with an over bar are assumed to be exogenous as part of the "closure rule" of the model. ${ }^{14}$ Besides, all variables at time (t-1) are exogenous at time $t$. The following set names also apply:

$\mathrm{a}=$ activities

$\mathrm{c}=$ commodities

$\mathrm{i}=$ institutions (i.e., households, enterprises, government, rest of the country, and rest of the world)

insdng $=$ domestic non-government institutions

$\mathrm{h}=$ households

$\mathrm{e}=$ enterprises

gov $=$ government

roc $=$ rest of the country (i.e., rest of Haiti)

row $=$ rest of the world

inv $=$ investment

invg $=$ government investment

invng $=$ non-government investment

\section{A.2. Equations and Variables}

Endogenous Variables

$A W F_{f, t} \quad$ average remuneration of factor $\mathrm{f}$

CALTFP $_{f, t} \quad$ tfp in calibration run

$C O N_{h, t} \quad$ household consumption expenditure

\footnotetext{
${ }^{14}$ The closure rule determines the mechanisms equalizing demand and supply in all markets featuring the model.
} 


\begin{tabular}{|c|c|}
\hline$C P I_{t}$ & consumer price index \\
\hline$D P I_{t}$ & index for domestic producer prices (PDS-based) \\
\hline$E G_{t}$ & gasto gobierno \\
\hline$E X R_{t}$ & exchange rate (dom. currency per unit of for. currency) \\
\hline$G A D J_{t}$ & government demand scaling factor \\
\hline$G F C F_{i n v, t}$ & gross fixed capital formation \\
\hline$I N D_{f, a, t}$ & non-gov investment by destination \\
\hline$K G_{i n v g, t}$ & government capital stock \\
\hline$M P S_{i, t}$ & marginal propensity to save for dom non-gov inst insdng \\
\hline$M P S A D J_{t}$ & savings rate scaling factor \\
\hline$P A_{a, t}$ & output price of activity a \\
\hline$P D D_{c, t}$ & demand price for comm c produced and sold domestically \\
\hline$P D E R_{c, t}$ & price for composite QD-QER \\
\hline$P D M R_{c, t}$ & price for composite QD-QMR \\
\hline$P D S_{c, t}$ & supply price for comm c produced and sold domestically \\
\hline$P E_{c, t}$ & export price for c (domestic currency) \\
\hline$P E R_{c, t}$ & RoC export price for c (domestic currency) \\
\hline $\operatorname{PINTA}_{a, t}$ & price of intermediate aggregate \\
\hline$P K_{i n v, t}$ & replacement cost of capital \\
\hline$P M_{c, t}$ & import price for c (domestic currency) \\
\hline
\end{tabular}




$\begin{array}{ll}P M R_{c, t} & \text { RoC import price for c (domestic currency) } \\ P Q_{c, t} & \text { composite commodity price for c } \\ P V A_{a, t} & \text { value-added price for activity a } \\ P X_{c, t} & \text { producer price for commodity c } \\ Q A_{a, t} & \text { level of activity a } \\ Q D_{c, t} & \text { quantity sold domestically of domestic output c } \\ Q D E R_{c, t} & \text { QD-QER aggregate for comm c } \\ Q D M R_{c, t} & \text { QD-QMR aggregate of comm c } \\ Q E_{c, t} & \text { quantity of exports for commodity c } \\ Q E R_{c, t} & \text { quantity of exports to RoC for commodity c } \\ Q F_{f, a, t} & \text { quantity demanded of factor f from activity a } \\ Q F S_{f, t} & \text { qupply of factor f oferta factor f } \\ Q G_{c, t} & \text { quantity of government demand for commodity c } \\ Q H_{c, h, t} & \text { quantity consumed of commodity c by household h } \\ Q I N T_{c, a, t} & \text { quantity of commodity c as intermediate input to activity a } \\ Q I N T A_{a, t} & \text { quantity of aggregate intermediate input } \\ Q I N V_{c, t} & \text { quantity of investment demand for commodity c } \\ Q M_{c, t} & \text { quantity of imports of commodity c } \\ Q R_{c, t} & \text { quantity of imports from RoC of commodity c } \\ & \end{array}$




\begin{tabular}{|c|c|}
\hline$Q R O C T_{c, t}$ & RoC tourism demand quantity of comm c \\
\hline$Q R O W T_{c, t}$ & RoW tourism demand quantity of comm c \\
\hline$Q T_{c, t}$ & quantity of trade and transport demand for commodity $\mathrm{c}$ \\
\hline$Q V A_{a, t}$ & quantity of aggregate value added \\
\hline$Q X_{c, t}$ & quantity of domestic output of commodity c \\
\hline$R E X R_{t}$ & real exchange rate \\
\hline$R G D P F C_{c, t}$ & real GDP at factor cost (at constant base-year prices) \\
\hline$R G F C F_{i n v, t}$ & real gross fixed capital formation \\
\hline$R S G_{t}$ & real government savings \\
\hline$S G_{t}$ & government savings \\
\hline $\mathrm{SH}_{i, t}$ & savings domestic non-government institution $\mathrm{i}$ \\
\hline$S_{R O C}$ & RoC savings (foreign currency) \\
\hline $\mathrm{SROW}_{t}$ & foreign savings (foreign currency) \\
\hline$T F P_{a, t}$ & total factor productivity index \\
\hline$T R_{i, i^{\prime}, t}$ & transfers from dom inst insdng to inst ins \\
\hline$U E R A T_{f, t}$ & unemployment rate for factor $\mathrm{f}$ \\
\hline$W A L R A S_{t}$ & dummy variable (zero at equilibrium) \\
\hline$W F_{f, t}$ & average price of factor $\mathrm{f}$ \\
\hline$W_{F D I S T} T_{f, a, t}$ & wage distortion factor for factor $\mathrm{f}$ in activity a \\
\hline$Y F_{f, t}$ & factor income \\
\hline
\end{tabular}




$$
\begin{array}{ll}
Y G_{t} & \text { government revenue } \\
Y H_{i, t} & \text { income of (domestic non-government) institution insdng } \\
Y I F_{i, f, t} & \text { income of institution ins from factor } \mathrm{f}
\end{array}
$$

Parameters and Exogenous Variables

$\begin{array}{ll}s h_{i, t}^{F} & \text { share for inst ins in the income of factor f } \\ \overline{m p s}_{i, t} & \text { marginal propensity to save for dom non-gov inst insdng } \\ \overline{q g}_{c, t} & \text { quantity of government demand for commodity c } \\ r g f c f_{i n v, t} & \text { real gross fixed capital formation } \\ t a_{a, t} & \text { rate of tax on producer gross output value } \\ t q_{c, t} & \text { rate of sales tax } \\ t y_{i, t} & \text { rate of direct tax on dom inst ins } \\ t f_{f, t} & \text { rate of direct tax on factor income } \\ t f a c t & \text { rate of factor use tax } \\ t e_{c, t} & \text { import } \\ t m_{c, t} & \text { export tax rate for commodity c } \\ p w h_{c, t} & \text { import tariff rate for commodity c } \\ & \\ & \end{array}$




\begin{tabular}{|c|c|}
\hline$p w m r_{c, t}$ & import price for c from RoC (foreign currency) \\
\hline$q d s t k_{c, t}$ & changes in inventories \\
\hline$i c d_{c, c^{\prime}}$ & trade and transport input of c per unit of comm cp produced and sold domest \\
\hline$i_{c e} e_{c, c^{\prime}}$ & trade and transport input of c per unit of comm cp exported \\
\hline$i c m_{c, c^{\prime}}$ & trade and transport input of c per unit of comm cp imported \\
\hline icer $_{c, c^{\prime}}$ & trade and transport input of $\mathrm{c}$ per unit of comm cp exported to RoC \\
\hline$i c m r_{c, c^{\prime}}$ & trade and transport input of c per unit of comm cp imported from RoC \\
\hline$\overline{\text { qroct }}_{c, c^{\prime}, t}$ & RoC tourism demand quantity of comm c \\
\hline$\overline{\text { qrowt }}_{c, c^{\prime}, t}$ & RoW tourism demand quantity of comm c \\
\hline$\delta_{f, a}^{V A}$ & share parameter for CES activity production fn \\
\hline$\phi_{a}^{V A}$ & efficiency parameter in the value added production fn for a \\
\hline$\sigma_{a}^{V A}$ & elasticity of substitution bt factors \\
\hline$\rho_{a}^{V A}$ & exponent in the value added production fn for a \\
\hline$t_{\text {tpexog }}{ }_{a, t}$ & exogenous component of sectoral TFP \\
\hline$\theta_{a, c}$ & yield of output $\mathrm{c}$ per unit of activity a \\
\hline$i c a_{c, a}$ & intermediate input c per unit of aggregate intermediate \\
\hline$i v a_{a}$ & aggregate value added coefficient for act a \\
\hline inta $_{a}$ & aggregate intermediate input coefficient for act a \\
\hline$\delta_{c, h}^{L E S}$ & marg shr of hhd cons on commodity c \\
\hline $\operatorname{qhmin}_{c}$ & subsist cons of com $\mathrm{c}$ for hhd $\mathrm{h}$ \\
\hline
\end{tabular}


$\delta_{c}^{M}$

$\delta_{c}^{D M R}$

$\phi_{c}^{Q}$

$\sigma_{c}^{Q}$

$\rho_{c}^{Q}$

$\delta_{c}^{E}$

$\delta_{c}^{D E R}$

$\phi_{c}^{X}$

$\sigma_{c}^{X}$

$\rho_{c}^{X}$

$\delta_{c}^{M R}$

$\delta_{c}^{D D}$

$\phi_{c}^{D M R}$

$\sigma_{c}^{D M R}$

$\rho_{c}^{D M R}$

$\delta_{c}^{E R}$

$\delta_{c}^{D S}$

$\phi_{c}^{D E R}$

$\sigma_{c}^{D E R}$

$\rho_{c}^{D E R}$
Armington function share parameter for imports commodity c

Armington function share parameter for composite QDMR commodity c

Armington function shift parameter for commodity c

elasticity of substitution bt. dom goods and imports for c

Armington function exponent for commodity c

CET function share parameter for exports commodity c

CET function share parameter for composite QDER commodity c

CET function shift parameter for commodity c

elasticity of transformation bt. dom sales and exports for c

CET function exponent for commodity c

Armington function share parameter for RoC imports commodity c

Armington function share parameter for domestic commodity c

Armington function shift parameter for commodity c

elasticity of substitution bt. dom goods and imports for c

Armington function exponent for commodity c

CET function share parameter for RoC exports commodity c

CET function share parameter for domestic commodity c

CET function shift parameter for commodity c

elasticity of transformation bt. dom sales and exports for c

CET function exponent for commodity c 


$$
\begin{array}{ll}
\eta^{\text {roct }} & \text { constant price elasticity of RoC tourism demand }(<0) \\
\eta^{\text {rowt }} & \text { constant price elasticity of RoW tourism demand }(<0) \\
c w t s_{c} & \text { consumer price index weights } \\
d w t s_{c} & \text { domestic sales price weights } \\
p h i l l i p s_{f} & \text { elasticidad-desempleo del salario factor f } \\
f p r d_{f, a, t} & \text { productivity term for factor f in act a } \\
\kappa & \text { qnty of commodity c per unit of investment inv } \\
c c_{c, i n v} & \text { depreciation rate for non-government capital } \\
\delta^{n g} & \text { depreciation rate for government capital } \\
\delta^{g} &
\end{array}
$$

\section{Equations}

\section{Production Function}

Top Level: Value Added Demand

$$
Q V A_{a}=i v a_{a} Q A_{a}
$$

Top Level: Intermediate Inputs Demand

$$
\operatorname{QINTA}_{a}=\operatorname{inta}_{a} Q A_{a}
$$

Second Level: Value Added

$$
\begin{aligned}
& Q A_{a}=T F P_{a} \phi_{a}^{V A}\left(\sum_{f} \delta_{f, a}^{V A}\left(\text { fprd }{ }_{f, a} F D_{f, a}\right)^{-\rho_{a}^{V A}}\right)^{\frac{-1}{\rho_{a}^{V A}}} \\
& \left.F D_{f, a}=\left(\frac{P V A_{a}}{W F_{f} W^{\prime} D I S T_{f, a}\left(1+t f a c t_{f, a}\right.}\right)\right)^{\sigma_{a}^{V A}}\left(\delta_{f, a}^{V A}\right)^{\sigma_{a}^{V A}}\left(T F P_{a} \phi_{a}^{V A}\right)^{\sigma_{a}^{V A}-1} Q V A_{a} f p r d_{f, a}^{\sigma_{a}^{V A}-1}
\end{aligned}
$$




$$
\operatorname{TFP}_{a}=t \text { fpexog }{ }_{a} C A L T F P \prod_{\text {invg }}\left(\frac{K G_{\text {invg }}}{K G_{\text {invg }}^{0}}\right)^{t \text { fpelas } s_{a, \text { invg }}}
$$

Second Level: Intermediate Inputs

$$
Q I N T_{c, a}=i c a_{c, a} Q I N T A_{a}
$$

Production Commodities

$$
Q X_{c}=\sum_{a} \theta_{a, c} Q A_{a}
$$

Production Prices

$$
\begin{aligned}
& P V A_{a} Q V A_{a}=P A_{a}\left(1-t a_{a}\right) Q A_{a}-P_{N T A_{a}} \text { INTA }_{a} \\
& \text { PINTA }_{a}=\sum_{c} P Q_{c} i c a_{c, a} \\
& P A_{a}=\sum_{c} \theta_{a, c} P X_{c}
\end{aligned}
$$

\section{Trade with Rest of the Country}

RoC Prices

$$
\begin{aligned}
& P M R_{c}=p w m r_{c}+\sum_{c t} P Q_{c t} i c m r_{c t, c} \\
& P E R_{c}=p_{w e r}-\sum_{c t} P Q_{c t} i c e r_{c t, c}
\end{aligned}
$$

Demand of Products -- QDD + QMR

$$
\begin{aligned}
& Q D M R_{c}=\phi_{c}^{D M R}\left(\delta_{c}^{M R} Q M R_{c}^{-\rho_{c}^{D M R}}+\delta_{c}^{D D} Q D_{c}^{-\rho_{c}^{D M R}}\right)^{-\frac{1}{\rho_{c}^{D M R}}} \\
& \frac{Q M R_{c}}{Q D_{c}}=\left(\frac{P D D_{c}}{P M R_{c}} \frac{\delta_{c}^{M R}}{\delta_{c}^{D D}}\right)^{\frac{1}{1+\rho_{c}^{D M R}}} \\
& P D M R_{c} Q D M R_{c}=P D D_{c} Q D_{c}+P M R_{c} Q M R_{c}
\end{aligned}
$$

Supply of Products -- QDS + QER 


$$
\begin{aligned}
& Q D E R_{c}=\phi_{c}^{D E R}\left(\delta_{c}^{E R} Q E R_{c}^{\rho_{c}^{D E R}}+\delta_{c}^{D S} Q D_{c}^{\rho_{c}^{D E R}}\right) \rho_{c}^{1} \rho_{c}^{D E R} \\
& \frac{Q E R_{c}}{Q D_{c}}=\left(\frac{P E R_{c}}{P D S_{c}} \frac{\delta_{c}^{D S}}{\delta_{c}^{E R}}\right)^{\frac{1}{\rho_{c}^{D E R}-1}} \\
& P D E R_{c} Q D E R_{c}=P D S_{c} Q D_{c}+P E R_{c} Q E R_{c}
\end{aligned}
$$

\section{International Trade}

World Prices

$$
\begin{aligned}
& P M_{c}=\left(1+t m_{c}\right) E X R \cdot p w m_{c}+\sum_{c t} P Q_{c t} i c m_{c t, c} \\
& P E_{c}=\left(1-t e_{c}\right) E X R \cdot p w e_{c}-\sum_{c t} P Q_{c t} i c e_{c t, c}
\end{aligned}
$$

Supply of Products -- Dom + Imp

$$
\begin{aligned}
& P D D_{c}=P D S_{c}+\sum_{c t} P Q D_{c t} i c d_{c t, c} \\
& Q Q_{c}=\phi_{c}^{Q}\left(\delta_{c}^{M} Q M_{c}^{-\rho_{c}^{Q}}+\delta_{c}^{D M R} Q D M R_{c}^{-\rho_{c}^{Q}}\right)^{-\frac{1}{\rho_{c}^{Q}}} \\
& \frac{Q M_{c}}{Q D M R_{c}}=\left(\frac{P D M R_{c}}{P M_{c}} \frac{\delta_{c}^{M}}{\delta_{c}^{D M R}}\right)^{\frac{1}{1+\rho_{c}^{Q}}} \\
& P Q_{c} Q Q_{c}=\left(P D R_{c} Q D M R_{c}+P M_{c} Q M_{c}\right)\left(1+t q_{c}\right)
\end{aligned}
$$

Demand of Products -- Dom + Exp

$$
\begin{aligned}
& Q X_{c}=\phi_{c}^{X}\left(\delta_{c}^{E} Q E_{c}^{\rho_{c}^{X}}+\delta_{c}^{D E R} Q D E R_{c}^{\rho_{c}^{X}}\right)^{\frac{1}{\rho_{c}^{X}}} \\
& \frac{Q E_{c}}{Q D E R_{c}}=\left(\frac{P E_{c}}{P D E R_{c}} \frac{\delta_{c}^{D E R}}{\delta_{c}^{E}}\right)^{\frac{1}{\rho_{c}^{X}-1}} \\
& P X_{c} Q X_{c}=P D E R_{c} Q D E R_{c}+P E_{c} Q E_{c}
\end{aligned}
$$




\section{Incomes and Savings}

Factors

$$
\begin{aligned}
& Y F_{f}=\sum_{a} W F_{f} W F D I S T_{f, a} F D_{f, a}+t^{t r n s f r_{f, r o w}} E X R+t r n s f r_{f, r o c} \\
& Y I F_{i, f}=s h_{i, f}^{F} Y F_{f}\left(1-t f_{f}\right)
\end{aligned}
$$

Domestic Non-Government Institutions; $i \in$ insdng

$$
\begin{aligned}
& Y H_{i}=\sum_{f} Y I F_{i, f}+\text { trnsfr }_{i, \text { gov }} C P I+\sum_{i^{\prime} \in \text { insdng }} T R_{i, i^{\prime}}+\text { trnsfr }_{i, \text { row }} E X R+\text { trnsfr }_{i, r o c} \\
& M P S_{i}=\overline{m p s}_{i} M P S A D J \\
& S H_{i}=m p s_{i} Y H_{i}\left(1-t y_{i}\right) \\
& T R_{i^{\prime}, i}=s h_{i^{\prime}, i}^{T R}\left(1-M P S_{i}\right)\left(1-t y_{i}\right) Y H_{i}
\end{aligned}
$$

Households

$$
C O N_{h}=\left(1-\sum_{i} s h_{i, h}^{T R}\right)\left(1-M P S_{h}\right)\left(1-t y_{h}\right) Y H_{h}
$$

Government

$$
\begin{aligned}
& Y G=\sum_{h} t y_{h} Y H_{h} \\
& +\sum_{c} t m_{c} E X R \cdot p w m_{c} Q M_{c} \\
& +\sum_{c} t e_{c} E X R \cdot p w e_{c} Q E_{c} \\
& +\sum_{a} t a_{a} P A_{a} Q A_{a} \\
& +t q_{c}\left(P D M R_{c} Q D M R_{c}+P M_{c} Q M_{c}\right) \\
& +\sum_{f} t f_{f} Y F_{f}+\sum_{f, a} W F_{f} W F D I S T_{f, a} F D_{f, a}{ }_{f} f a c t_{f, a} \\
& + \text { trnsfr } r_{\text {gov }, \text { row }} E X R+\text { trnsfr } r_{\text {gov,roc }}+\sum_{\text {insdng }} T R_{\text {gov,insdng }} \\
& +\sum_{f} Y I F_{g o v, f} \\
& E G=\sum_{c} P Q_{c} Q G_{c}+\sum_{i \in i n s d n g} t_{n} n f r_{i, g o v} C P I+\text { trnsfr }_{\text {row,gov }} E X R+\text { trnsfr }_{\text {roc,gov }}
\end{aligned}
$$




$$
\begin{aligned}
& S G=Y G-E G \\
& R S G=\frac{S G}{C P I}
\end{aligned}
$$

Rest of the World

$$
\begin{aligned}
& \sum_{c} p w e_{c} Q E_{c}+\sum_{a c} \text { trnsfr }_{a c, \text { row }}+\frac{\sum_{c} P Q_{c} Q R O W T_{c}}{E X R}+S R O W= \\
& \sum_{c} p w m_{c} Q M_{c}+\text { trnsfr }_{\text {row }, \text { gov }}+\frac{\sum_{i \in \text { insdng }} T R_{\text {row }, i}}{\overline{E X R}}+\frac{\sum_{f} Y I F_{r o w, f}}{\overline{E X R}}
\end{aligned}
$$

Rest of the Country

$$
\begin{aligned}
& \sum_{c} \text { pwee }_{c} Q E R_{c}+\sum_{a c} \text { trnsfr }_{a c, r o c}+\sum_{c} P Q_{c} Q R O C T_{c}+S R O C= \\
& \sum_{c} p w m r_{c} Q M R_{c}+t r n s f r_{r o c, g o v}+\sum_{i \in \text { insdng }} T R_{r o c, i}+\sum_{f} Y I F_{r o c, f}
\end{aligned}
$$

\section{Final Consumption}

Households

$$
Q H_{c, h}=q h \min _{c, h}+\frac{\delta_{c, h}^{L E S}}{P Q_{c}}\left(C O N_{h}-\sum_{c^{\prime}} P Q_{c^{\prime}} q^{\prime} h \min _{c^{\prime}, h}\right)
$$

Investment

$$
Q I N V_{c}=\sum_{i n v} c c_{c, i n v} R G F C F_{i n v}
$$

Government

$$
Q G_{c}=\overline{q g}_{c} G A D J
$$

Trade and Transport Margins

$$
Q T_{c}=\sum_{c^{\prime}}\left(i c m_{c, c^{\prime}} Q M_{c^{\prime}}+i c e_{c, c^{\prime}} Q E_{c^{\prime}}+i c d_{c, c^{\prime}} Q D_{c^{\prime}}+i c m r_{c, c^{\prime}} Q M R_{c^{\prime}}+i c e r_{c, c^{\prime}} Q E R_{c^{\prime}}\right)
$$

Tourism Demand (RoC and RoW); exogenous if eta_roct $=0$ and eta_rowt $=0$ 


$$
\begin{aligned}
Q R O C T_{c} & =\overline{\operatorname{qroct}}_{c}\left(\frac{P Q_{c}}{P Q_{c}^{0}}\right)^{\eta^{\text {roct }}} \\
\mathrm{QROWT}_{c} & =\overline{\operatorname{qrowt}}_{c}\left(\frac{P Q_{c} / E X R}{P Q_{c}^{0} / E X R^{0}}\right)^{\eta^{\text {rowt }}}
\end{aligned}
$$

\section{Unemployment}

$$
\frac{W F_{f}}{C P I}=\frac{W F_{f}^{0}}{C P I^{0}}\left(\frac{U E R A T_{f}}{U E R A T_{f}^{0}}\right)^{\text {phillips }_{f}}
$$

\section{Equilibrium Conditions}

Factor Markets

$$
F S_{f}\left(1-U E R A T_{f}\right)=\sum_{a} F D_{f, a}
$$

Commodity Markets

$$
\begin{aligned}
& \sum_{h} Q H_{c, h}+\sum_{a} Q I N T_{c, a}+Q I N V_{c}+Q G_{c}+Q T_{c}+q d s t k_{c} \\
& +Q R O C T_{c}+Q R O W T_{c}=Q Q_{c}
\end{aligned}
$$

Savings-Investment

$$
\sum_{c} P Q_{c} q d s t k_{c}+\sum_{i n v} G F C F_{i n v}=\sum_{i \in i n s d n g} S H_{i}+S G+E X R . S R O W+S R O C
$$

\section{Miscellaneous}

Consumer Price Index

$$
\sum_{c} P Q_{c} c w t s_{c}=C P I
$$

Index for Domestic Producer Prices

$$
\sum_{c} P D S_{c} d w t s_{c}=D P I
$$

Real Exchange Rate 


$$
R E X R=\frac{E X R}{D P I}
$$

Real GDP at Factor Cost

$$
R G D P=\sum_{a} P V A_{a}^{00} Q V A_{a}
$$

\section{Investment by Destination; Dynamics}

$$
\begin{aligned}
& P K_{i n v}=\sum_{c} c c_{c, i n v} P Q_{c} \\
& R G F C F_{i n v}=\frac{G F C F_{i n v}}{P K_{i n v}} \\
& A W F_{f}=\frac{\sum_{a} F D_{f, a} W F_{f} W F D I S T_{f, a}}{\sum_{a} F D_{f, a}} \\
& I N D_{k, a}=R G F C F_{i n v n g} \frac{F D_{k, a}}{\sum_{a^{\prime}} F D_{k, a^{\prime}}}\left[1+\kappa\left(\frac{W F_{k} W F D I S T_{k, a}}{A W F_{k}}-1\right)\right] \\
& F D_{k, a}=\left(1-\delta_{k}^{n g}\right) F D_{k,-1}+I N D_{k, a,-1}
\end{aligned}
$$

Government RGFCF

$$
\begin{aligned}
& R G F C F_{i n v}=r g f f_{i n v g} \\
& K G_{\text {invg,a }}=\left(1-\delta^{g}\right) K G_{\text {invg,-1 }}+R G F C F_{\text {invg, }-1}
\end{aligned}
$$

